\title{
Polity Size and the Institutionalization of Leadership Succession
}

John Gerring (UTA) and Carl Henrik Knutsen (UiO)

\begin{abstract}
$\underline{\text { Abstract }}$
Why is leadership succession highly institutionalized in some polities but not in others? We propose that the size of the polity constitutes a key explanatory factor. Specifically, we argue that an institutionalized process of succession is more likely to be adopted in larger polities because there are more elite actors vying for power, making it difficult for a single actor to consolidate power, hold it indefinitely, and pass it on to his heirs. To test this argument, we construct a global index centering on observable features of leadership succession. The index, drawing on data from the Archigos project, covers most sovereign countries from the mid-nineteenth century to the present. A battery of crossnational tests shows a positive and robust association between polity size and the institutionalization of leadership succession.
\end{abstract}


Leaders do not live forever. Consequently, every polity faces the challenge of leadership succession: many elites aspire to rule and there is generally only one top position available. A great deal hinges on who wins this contest for power including the distribution of patronage, the protection or prosecution of friends and enemies, and the course of public policy. Studying economic growth, Jones \& Olken (2005) show that leadership succession is especially consequential in autocracies, where the prerogatives of top leaders are less constrained.

Leadership succession also has important repercussions for domestic peace and regime stability. Poorly managed transitions are often accompanied by conflict, e.g., "wars of succession” (Jones \& Olken 2009; Miller 2012; Wolford 2016). Autocratic regimes are especially vulnerable during periods of transition (Kokkonen \& Sundell 2014; Kurrild-Klitgaard 2000, 2004; Treisman 2015; Tullock 1987). Ezrow \& Frantz (2011: 6) report that "of the 340 leadership transitions that occurred in dictatorships from 1946 to 2009, 160 brought the regime down,” and Frantz \& Stein (2017) show that succession rules affect susceptibility to coups.

Leadership succession, finally, is indicative of institutionalization in the top office. Most leaders would prefer to prolong their tenure in office indefinitely and, when the time is right (perhaps at their demise), pass on their power and prerogative to a family heir. Wherever political succession occurs regularly, in an orderly and lawful manner, and is not restricted to family heirs, this presumably happens because leaders are compelled to follow these rules. Institutions are constraining.

While the exercise of power is difficult to observe, the passage of power is fairly transparent. We are generally able to ascertain when power passes from one person to another and the circumstances of that transition. At this crucial moment, regimes often reveal their true colors (Alvarez, Cheibub, Limongi \& Przeworski 1996). Indeed, the point at which rules of succession are regularized, has long been regarded as an indication that a regime is institutionalized (Bunce 1981; Calvert 1987). For example, the leadership transition in China from Jiang Zemin to Hu Jintao signaled that 
formal rules and compliant procedures have prevailed over factional politics based on informal personal relations among the political elites of the Chinese Communist Party (CCP). The smoothness of the Jiang-Hu transition is the result of the growing institutionalization of the political process, which explains why Jiang's political clout has substantially eroded since his retirement. ${ }^{1}$

Likewise, if Xi Jinping (the current president) is able to prolong his tenure, abrogating norms of regular leadership succession, or if the next transition is accompanied by conflict, Sinologists may rightly conclude that the system is becoming deinstitutionalized.

In this study, we focus on the question of why practices of leadership succession are highly institutionalized in some polities and ad hoc, irregular, or nepotistic in others. Although the topic of succession has attracted scholarly attention (Bienen \& Van de Walle 1991; Burling 1974; Goody 1966; Govea \& Holm 1998; Kokkonen \& Sundell 2014; Kurrild-Klitgaard 2000), there is no established explanation for why transitions occur more often, and more regularly, in some settings than in others. Evidently, democracy plays an important role; however, even across countries that share the same regime-type there is enormous variation. Some autocracies are more institutionalized than others, just as some democracies are more institutionalized than others. Many proximal factors such as civil wars or popular uprisings are also likely to affect leadership succession.

In this paper, we focus on a structural factor that may be regarded as highly exogenous, at least with respect to regime-type, civil war, and other political factors. We argue that practices of leadership succession are conditioned by the size of a polity. Larger polities (with more citizens) are more likely to develop institutionalized processes of leadership succession.

The rationale may be briefly stated. Larger polities typically have more elite actors vying for power, making it more difficult, and riskier, for a single actor to consolidate power, hold it

\footnotetext{
${ }^{1}$ Huang (2008: 80-81).
} 
indefinitely, and pass it on to his/her heirs. Moreover, larger polities may increase demands from citizens to develop institutionalized solutions to the succession issue, as it is harder for citizens to monitor and coordinate pressure against elites in large polities.

In Section I, we present our argument. In Section II, we elaborate on our conceptualization of institutionalization and introduce a novel index of leadership succession extending from 1840 to 2012. In Section III, we test our hypothesis using different specifications and estimators. These tests reveal a robust association between polity size and leadership succession. Section IV recapitulates the argument and discusses its generalizability.

\section{Argument}

Institutionalization refers here to a process of leadership transition that is regular, orderly, ruleabiding, and non-nepotistic. Larger polities, we propose, are apt to develop more institutionalized systems of leadership succession than smaller ones. To explain this dynamic we offer two complementary accounts, the first resting on the incentives facing elites and the second on incentives facing rank-and-file citizens.

\section{Elites}

Every country has a number of powerful actors, aka elites. We assume that each elite actor is linked to a set of followers whom the actor represents (albeit perhaps in a less-than-perfect fashion). This support base might be located in the military, a sector of the economy, a religious organization, an ethnic group, or some other body. Elites have a strong stake in how power is organized within a polity. They and their supporters stand to benefit if they control the apex of power. They may lose everything if a rival gains power. 
Because they represent powerful social bases, elites are often in a position to hamper a smooth leadership transition. If unhappy with the process, or the choice, they may refuse to recognize the successor, remove their support from the regime, or even take action to mobilize their supporters. As we have emphasized, successions are moments fraught with peril. Departing leaders, and their successors, look eagerly - sometimes desperately - to elites to validate each change of power. Because their consent is essential for a smooth transition, we regard elites (loosely) as "veto holders."

We assume that all elites would prefer to hold power and to exercise it in an unconstrained fashion in perpetuity. This is their ideal-point. If they are unable to do so, we presume that they would prefer to impose limits on the exercise of power by others. Whether or not elites support an institutionalized system of leadership succession depends, therefore, upon where they sit.

Following this logic, elite preference-orderings may be summarized as the intersection of two dimensions: (1) who holds power (understood as control over the executive office) and (2) whether that power is limited. Within this matrix, illustrated in Table 1, all actors have the same overall preference orderings: $A$ (to hold power without constraints) $>B$ (to hold power with constraints) $>C$ (to be out of power in a system with constraints) $>D$ (to be out of power in a system without constraints).

Table 1: Power and Preferences

\begin{tabular}{lcc|c|} 
& \multicolumn{2}{c}{ Limit Power } \\
& & No & \multicolumn{1}{c}{ Yes } \\
\cline { 3 - 4 } Hold power & Yes & $A$ & $B$ \\
\cline { 3 - 4 } & No & $D$ & $C$ \\
\cline { 3 - 4 } & & &
\end{tabular}

Preference-ordering: $A>B>C>D$. 
The most consequential distinction among different elites is thus between the incumbent (the current officeholder) and non-incumbents. All else equal, incumbents prefer a noninstitutionalized system based on the current power configuration $(A>B)$. This means that they can rule without interference until their demise or chosen retirement, passing on power to someone of their own choosing (e.g. a close family member or ally). Non-incumbents, by contrast, prefer to institutionalize power $(C>D)$, and in particular the process of leadership succession - offering hope that they, or their allies, may occupy the top position at some point in the not-too-distant future.

While these preference rankings may be the same in smaller and larger polities, the relative distance between the alternative outcomes, and thus the preferred choice on whether or not to institutionalize leadership succession for (forward-looking) elites,depends on polity size.

We presume that the size of a community is related to the number of elite actors. A larger community produces more elite actors, each with their own support base. We elaborate on, empirically assess, and justify this non-obvious assumption, which is central to our argument, in Appendix D. If this assumption holds, we can make the following observation: Since only one elite can occupy the top office (in this simplified schema), the ratio of non-incumbents to incumbents increases monotonically with community size. This feature, in turn, makes it more difficult for any single elite player to obtain, and to secure for his lifetime, untrammeled exercise of power. The current leader, although he might rule in an absolute fashion, must be concerned about threats to his/her power as there are many who plot his/her demise - namely, all the elites currently excluded from power.

Likewise, if the incumbent loses power, through some unfortunate circumstance, the probability of regaining power is lower, ceteris paribus, in a larger polity, as there are more elites contesting for the throne. Thus, an incumbent leader of a large polity faces the prospect of ending up in scenario $D$ perpetually, unless s/he institutionalizes leader succession. 
Granted, a larger number of non-incumbent elites also enhances coordination challenges among the aspirants. This might play into the hands of the incumbent, who could divide the opposition and thereby resist calls for institutionalization. Yet, it is important to appreciate that the coordination problem facing elites is often much less challenging than the coordination problem facing citizens, as a product of their greatly reduced numbers (Houle 2009).

Likewise, the coordination problem among non-incumbent elites is mitigated by a shared goal - limiting the incumbent's power. Only in this fashion can they constrain the depredations of the current ruler and enhance the probability of holding office themselves one day. (Note that when leadership succession is institutionalized, turnover is more frequent and access is not limited to friends and relatives of the current ruler.) Because their incentives align on this crucial point, coordination challenges may be surmountable. Non-incumbent elites may band together in a grand coalition, paving the way for power-sharing institutions that constrain current and future rulers (Bratton and van de Walle 1997; Chenoweth and Stephan 2011; Collier 1999). Importantly, our argument does not hinge entirely on successful coordination among non-incumbent elites. For, even when acting independently these elites still pose considerable danger to the incumbent. They may passively resist, withdrawing their support from the regime, refusing to pay taxes or to enforce the law over territory under their control. They may also sponsor violent reprisals. Elites may have the capacity to wage costly civil insurrections, which can compromise the security of the regime and provide an opening for aggrieved parties to make claims for autonomy or independence. In short, non-incumbent elites can do a great deal of damage, lowering the value and power of the top office, and reducing the expected longevity of the current leader. With more non-incumbent elite actors, the likelihood that incumbents will face costly challenges increases in a large polity. Indeed, population size is a robust predictor of civil war (Hegre \& Sambanis 2006).

These structural features of large communities alter incentives for all elites - the incumbent and non-incumbents, who must consider the prospects of ruling if they should ever 
obtain the leadership position. While everyone's ideal-point remains $A$, elites may acclimate themselves to the prospect of $B$ or $C$ if $A$ seems unattainable over the long term. In large polities with many contending elite groups, the shadow of the future presents leaders with the bleak prospect of being out of power one day in a non-institutionalized system $(D)$. This is the worst possible outcome since one's possessions and one's very life are in jeopardy. Consequently, nonmyopic leaders may prefer to institutionalize leadership succession today, trading off current losses (going from $A$ to $B$ ) for future gains (going from $D$ to $C$ ) (see also Boix \& Svolik 2013; Svolik 2012). As recognized by the civil war literature, one way to mitigate the risk of bargaining failures is through institutions that reduce information asymmetries and mitigate commitment problems (e.g., Walter 2009). Here, we are focused on institutions governing the process of leader succession.

Our stylized narrative treats elites as unitary actors, leaving aside the possibility of alliances. A single actor could assure his longevity, and the longevity of his family or clan, by forming strategic alliances with other actors. However, a voluntary alliance of this nature would necessitate an exchange. The ruling actor presumably forfeits some powers to obtain the consent of various allies. In this fashion, power is effectively constrained. Such an agreement might lead, eventually, to an institutionalized system of leadership succession - for, if practices of succession are unconstrained it will be difficult for allies to exert any control over policies. The prospect of alliances among rival elites is, in fact, an important mechanism by which power becomes institutionalized in a setting with many rival elites.

In summary, we anticipate that an institutionalized system of succession is more likely to be achieved as the size of a community increases. In larger communities, there are more elite actors striving for power, making it harder for any single leader to establish power and maintain it indefinitely, passing it on to family members when s/he retires or dies. Facing this reality, elites - including the incumbent -have an interest in establishing a regularized system for ensuring the circulation of elites in the top office, thereby sharing power over the long haul. In this respect, 
practices of leadership succession instantiate the principle of shared rule, even though each ruler may hold substantial power while occupying the executive office (see also Przeworski 1991).

\section{Citizens}

Politics may be viewed as a massive coordination problem in which citizens with diverse preferences must agree on policies and assure that those policies are faithfully carried out, monitoring the behavior of political leaders and holding them accountable.

Coordination and monitoring may be accomplished in an informal manner, through informal, personal relationships among citizens and leaders, or they may be accomplished in a formal manner, through explicit rules that govern the exercise of power and constrain leaders. We argue that a formal, institutionalized approach is more likely to appear in larger organizations because size increases coordination challenges among citizens and decreases the viability of informal institutions.

Accountability is likely enhanced by tight social networks. In small polities, leaders and citizens are likely to belong to the same churches, clubs, and schools. They are likely to intermingle at bars, restaurants, weddings, and funerals, and regular interaction presumably eases communication and coordination. Small societies are cohesive in this respect, and citizens should find it easier to influence politics through informal channels. Insofar as informal channels suffice to hold leaders accountable, there is less reason to invest heavily in institutionalizing power at the apex in smaller polities.

Relatedly, consider the problem of collective action which all mass publics face. One persistent finding is that size impedes collective action (Olson 1965). Informal channels of political communication - conversation, letters, petitions, media campaigns, protests, and so forth - involve extraordinary collective action challenges. They are "expensive" in terms of time and money (understood as direct expenses and foregone income) relative to formal mechanisms of mass participation such as voting. Consequently, people are much less likely to participate in 
letter-writing campaigns or street protests than elections (Verba et al. 1995). While collective action problems increase with size, the gradient of this relationship is hence especially steep for participation in informal institutions. The larger the polity, the less effective informal mechanisms of political organization and communication are likely to be. If so, citizens in a large polity have greater incentives to support, and defend, an institutionalized system of politics centered on formal rules rather than informal practices.

Consider leadership succession. In a small polity, whoever rules will be accessible, monitorable, and to some extent accountable by virtue of the diminutive size the community and the availability of informal mechanisms of voice and exit. Rigid rules may be dispensed with among family members, and there is a sense in which citizens of a small polity are members of the same extended family. For example, an executive who over-stays his/her term limit, who appoints a personal relation as a successor, or who grants government business to a close friend may be excused if a majority of those living in the polity feel that they are part of that exclusive club of beneficiaries. "He's a scoundrel, but he's our scoundrel," may be the general attitude among those who count themselves clients of the executive.

By contrast, in a large polity we can expect citizens to be extremely concerned about the monopolization of power in the hands of a single person over extended time, and further hereditary succession, as leaders cannot be controlled through informal channels and there is a high probability of disjuncture between the leader and the citizenry. Here, citizens are more likely to insist that rules be followed, as they are the only way in which their interests will be respected, now and in the future.

Granted, the imposition of a rule-based system of leadership succession does not appear simply because citizens embrace such a regime. Citizens must act to defend their interests, and acting involves solving their collective action problem. However, the coordination required to impose and defend an institutionalized system of leadership succession is orders of magnitude 
lower than the coordination required to monitor and punish political leaders on a day-to-day basis.

Also, the modernization process - including enhanced wealth, education, and transport and communications infrastructure - reduces the burden of coordination, making it more feasible for citizens to act in defense of their interests. Coordination problems that impeded the mobilization of citizens in large polities in pre-modern times (Stasavage 2010, 2011) are less forbidding. This point to an important scope-condition of our argument. We expect that the relationship between polity size and the institutionalization of leadership succession is higher in the present era than in previous historical eras.

\section{Conceptualization and Measurement}

At its core, an institutionalized system of leadership succession is one governed by rules rather than rulers (or their families). It is a depersonalized system, where merit (achievement) rather than ascriptive characteristics or personal connections to the current ruler governs selection, where succession is regular (not one in which rulers rule until they expire), and where the process is orderly (following constitutional law or well-established principles). Institutionalization thus carries many of the characteristics associated with legal-bureaucratic rationality (Weber 1961).

We make two observations at the outset that we will return to. First, succession processes can be broken down into the exit of the incumbent leader and the subsequent entry of the new leader. Both processes may or may not be governed by rules. We thus need indicators capturing features of both leader exit and entry. Second, while certain rules and formal institutional arrangements may be causally related to institutionalized leader succession, we remark that the concept itself entails a focus on practices and the extent to which the rules supposed to govern leader succession are actually followed, not the specific contents of these rules. 
According to the standard laid out above, a monarchy - defined as a system in which executive power is passed down to family members - is more institutionalized than a polity where there is no established method of succession, leaving contenders to fight it out using whatever method is available. Yet, all monarchies limit access to office to royal family members and allow the chosen ruler to hold office unto death, a personalization of power directly at odds with the Weberian ideal. Thus, we regard monarchies as semi-institutionalized forms of governance. Much depends, of course, on whether, or to what degree, constitutional rules are followed. By the standard of practice, some monarchies were more institutionalized than others (Duindam 2015).

Following our definition, one would expect democracies to have the most institutionalized practices of leadership succession. However, not all democracies are highly institutionalized. In the Philippines, for example, nepotism runs amok (Mendoza et al. 2012). Likewise, not all autocracies exhibit ad hoc or personalistic systems of leadership succession. China post-Mao (Ebrey 2006; Miller 2008; Zeng 2014) and Mexico under PRI dominance (Magaloni 2006) are obvious exceptions. Indeed, practices vary considerably within regime-types that might be classified broadly as democratic or authoritarian. Although democraticness is associated with institutionalization, it is not very highly correlated. ${ }^{2}$ In the empirical tests to follow, we control for democracy (Table 2) and provide split-sample tests limited to democracies and autocracies (Table C1) in order to show that the outcome of theoretical interest institutionalization - is not serving as a proxy for democracy.

We should also distinguish institutionalized leadership succession from the more general concept, 'political stability'. Highly institutionalized polities are presumably more stable; breaches to rules for leadership succession may lead to conflict among elite groups, as anticipated by our

\footnotetext{
2 The correlation coefficients (Pearson's r) between our index (described below) and measures of democracy such as Polity2 (Marshall et al. 2014), LIED (Skaaning et al. 2015), and Polyarchy (Teorell et al. 2017) range from .61 to .62.
} 
theoretical argument. Thus certain forms of instability, such as civil war, may be a consequence of weak institutionalization. Likewise, certain forms of political instability, for instance revolutions or coups d'état, may cause violations to constitutional rules of succession. Despite these (likely) causal linkages we maintain that institutionalization of leader succession and political stability are conceptually distinct. In some of the empirical analysis below, we control for particular forms of instability when assessing the link between size and institutionalized leader succession.

\section{Indicators}

Having discussed the concept of leadership institutionalization we turn to measurement. As noted, leadership succession entails both the exit of an incumbent leader and the entry of a new one. Hence, we require indicators on the compliance with extant rules for both parts of the process for our measure to be valid. Further, other indicators that capture different features of institutionalization or that serve as indirect signals of (lack of) institutionalization may be added to our overall measure to enhance reliability. Thus, we draw on five indicators from Archigos (Goemans, Gleditsch \& Chiozza 2016) to construct an index of institutionalized leadership succession.

We deem leadership succession to be highly institutionalized when the following criteria are met. First, the previous executive leaves office in a regular fashion. That is, the process follows established principles and precedents as set out in a constitution or basic law. This excludes circumstances such as coups, seizure of power by another body, or forced withdrawal (in contravention of constitutional rules or norms). Second, the former executive is at liberty, i.e., does not face imprisonment, harassment, exile, or death because of actions taken while in office. (Note that a prosecution for actions taken while occupying executive office indicate either that the executive violated the law or that $\mathrm{s} /$ he is being persecuted for political reasons. Both constitute a breach of constitutional protocol.) Third, the current executive is chosen through 
regular procedures, as laid out in a constitution or basic law. Fourth, the current executive has no family connection to any previously serving executive - a connection that we regard as prima facie evidence of nepotism, including special advantages available to members of a well-connected family (Querubin 2016), and hence of personal rule. Finally, the current executive has been in office for a decade or less. We regard longer terms, even if constitutionally sanctioned, as prima facie evidence that power has been personalized and that the executive is not bound by institutions (Svolik 2012).

Importantly, these indicators focus on actual practices rather than written rules. Formal rules are irrelevant, from our perspective, unless they are followed. Certainly, de facto practices are sometimes harder to determine than de jure rules, imposing a more difficult task for coders classifying individual cases. Yet, our topic is highly salient and fairly transparent. Coders may rely on a rich historical record produced by journalists and historians, and are generally able to make informed judgments on these five issues.

We draw these indicators from the Archigos dataset. Coding rules laid out in the Archigos codebook are accompanied by extensive case descriptions (Goemans, Gleditsch \& Chiozza 2016). In most instances, the circumstances of a case seem fairly clear. In others, knowledgeable observers might have different interpretations for how to code criteria 1-4. While acknowledging the inevitability of error, we do not anticipate systematic biases in measurement that might affect questions at issue in this study.

All five criteria are understood in a binary fashion, coded 1 if a criterion is satisfied and 0 otherwise. Coding is constant in between leadership transitions, implying that there is no missing data and a panel structure can be adopted.

We aggregate these indicators into a single index by addition. The rationale behind this simple approach is that all five elements of institutionalization matter, they are partly substitutable, and one is at pains to determine which matter more. Under the circumstances, equal weighting provides a convenient and plausible method of aggregation that is also easy to 
interpret. This index is our primary measure of leadership institutionalization, though alternate methods of aggregation are tested.

Data stretches from 1840-2012, covering 175 sovereign countries. Scores vary from $0-5$, with a mean of 3.3 , standard deviation of 1.5 , and mode at 5 . Over time, we find increasing levels of institutionalization, as shown in Figure 1. This increase is especially marked when considering only countries with data for at least a century, producing a (somewhat) constant sample. Mean institutionalization scores in the mid-nineteenth century hover between 2 and 3 , while they surpass 4 in the late twentieth century (for the restricted sample).

\section{Figure 1: Leadership Succession Institutionalization through Time}

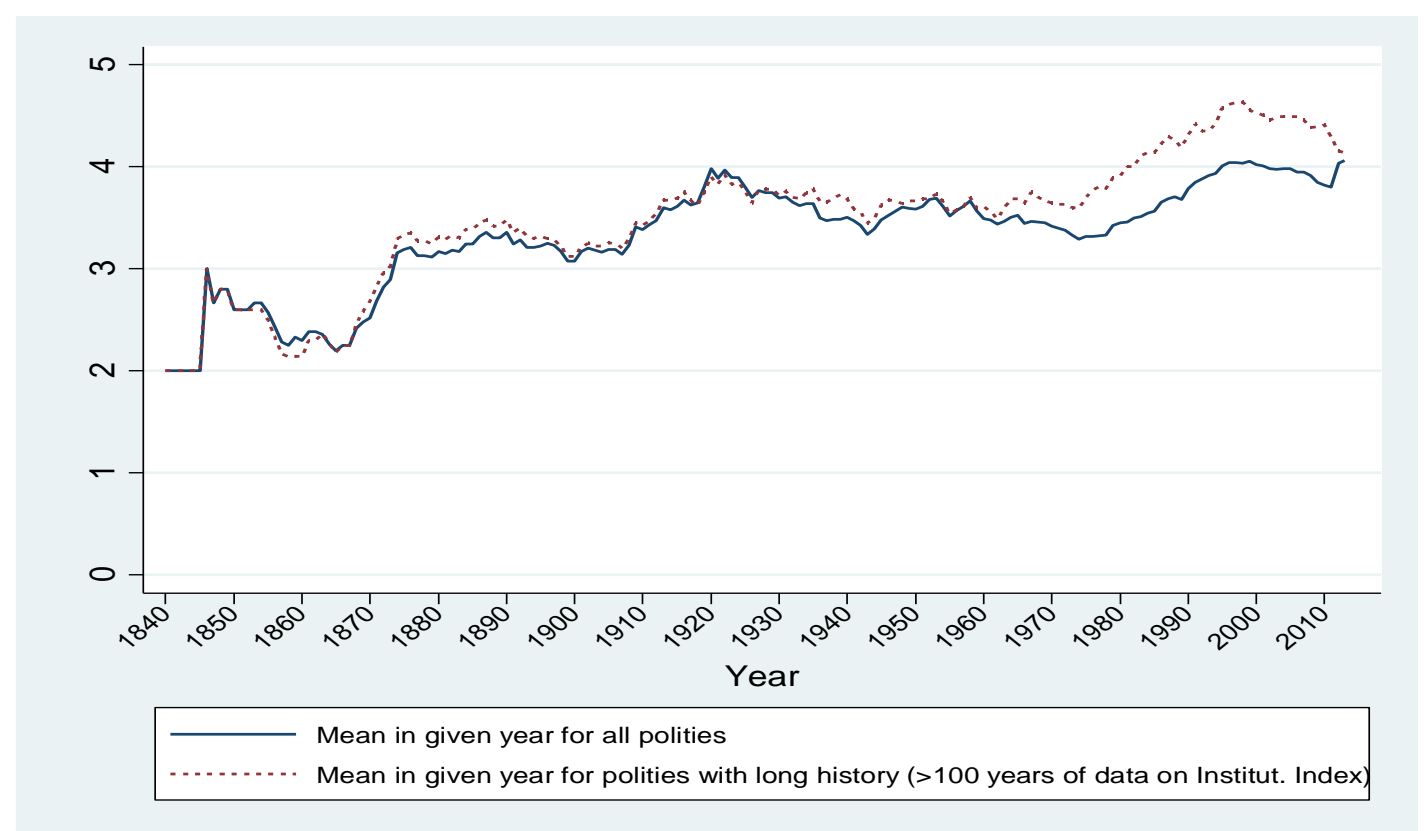

\section{Analysis}

To test our argument, we regress our index of leadership succession institutionalization on polity size in a global panel of countries. Since the effect of size on institutionalization is anticipated to be concave, with increases in size having decreasing marginal effects, we operationalize this 
variable as a logarithmic transformation of population. (Results reported below are nonetheless robust when a linear measure of population is employed.)

Empirical tests privilege cross-sectional comparisons rather than longitudinal comparisons. This choice is grounded in the nature of our data and the expected relationship of theoretical interest. Note, first, that both right- and left-side variables of theoretical interest are sluggish; hence, most of the available variation in our country-year sample is cross-sectional rather than longitudinal. Second, the relationship between country size and institutionalization is likely to be distal and we do not know what the proper lag might be. Third, short-term changes in a country's population are often driven by background factors - e.g., war, ethnic cleansing, famine, plague - that may serve as confounders, and which are difficult to control for.

For all these reasons it makes little sense to try to gauge the impact of a small change in population on a country's institutionalization score, as one might with fixed-effect or firstdifference estimators. ${ }^{3}$ Instead, we lean primarily on cross-sectional comparisons in our baseline specifications, while controlling for (country-specific and time varying) features that may serve as confounders. We also conduct several robustness tests, including generalized methods of moments specifications that are designed to simultaneously account for country-specific effects and the sluggish nature of the variables.

\footnotetext{
${ }^{3}$ Standard errors are much larger and the relationship between size and leader institutionalization insignificant at conventional levels when adding country-fixed effects to our benchmark. This is despite the coefficient being substantially larger in size than in the benchmark.
} 
Table 2: Initial Tests

\begin{tabular}{|c|c|c|c|c|c|c|c|c|c|c|}
\hline Estimator & OLS & OLS & OLS & OLS & OLS & OLS & OLS & O.logit & $\mathrm{RE}$ & GMM \\
\hline Sample & Full & Full & Full & Full & Full & Full & Imputed & Full & Full & Full \\
\hline Lag (years) & $\begin{array}{l}20 \\
\text { (1) }\end{array}$ & $\begin{array}{l}100 \\
(2)\end{array}$ & $\begin{array}{l}20 \\
\text { (3) }\end{array}$ & $\begin{array}{l}20 \\
(4)\end{array}$ & $\begin{array}{l}20 \\
\mathbf{( 5 )}\end{array}$ & $\begin{array}{l}20 \\
(6)\end{array}$ & $\begin{array}{l}20 \\
\mathbf{( 7 )}\end{array}$ & $\begin{array}{l}20 \\
(\mathbf{8})\end{array}$ & $\begin{array}{l}20 \\
(9)\end{array}$ & $\begin{array}{c}10 \\
(10)\end{array}$ \\
\hline Population (ln) & $\begin{array}{c}0.163^{* * *} \\
(0.046)\end{array}$ & $\begin{array}{c}0.167 * * \\
(0.072)\end{array}$ & $\begin{array}{c}0.149 * * * \\
(0.047)\end{array}$ & & $\begin{array}{c}0.163^{* * *} \\
(0.044)\end{array}$ & $\begin{array}{c}0.141 * * * \\
(0.052)\end{array}$ & $\begin{array}{c}0.052 * \\
(0.031)\end{array}$ & $\begin{array}{c}0.331^{* * *} \\
(0.088)\end{array}$ & $\begin{array}{c}0.196^{* *} \\
(0.084)\end{array}$ & $\begin{array}{c}0.238^{* *} \\
(0.117)\end{array}$ \\
\hline ...2d quartile & & & & $\begin{array}{c}1.012^{* *} \\
(0.493)\end{array}$ & & & & & & \\
\hline ...3d quartile & & & & $\begin{array}{c}1.158^{* *} \\
(0.500)\end{array}$ & & & & & & \\
\hline$\ldots 4^{\text {th }}$ quartile & & & & $\begin{array}{c}1.403^{* * *} \\
(0.498)\end{array}$ & & & & & & \\
\hline GDP per cap $(\ln )$ & $\begin{array}{c}0.366^{* * *} \\
(0.103)\end{array}$ & $\begin{array}{c}0.094 \\
(0.174)\end{array}$ & $\begin{array}{c}0.454 * * * \\
(0.072)\end{array}$ & $\begin{array}{c}0.465^{* * *} \\
(0.069)\end{array}$ & $\begin{array}{c}0.295^{* * *} \\
(0.101)\end{array}$ & $\begin{array}{c}0.309^{* * *} \\
(0.109)\end{array}$ & $\begin{array}{c}0.221 * * * \\
(0.069)\end{array}$ & $\begin{array}{c}0.588^{* * *} \\
(0.202)\end{array}$ & $\begin{array}{c}0.199 \\
(0.159)\end{array}$ & $\begin{array}{l}-0.203 \\
(0.154)\end{array}$ \\
\hline Urbanization & $\begin{array}{c}0.005 \\
(0.004)\end{array}$ & $\begin{array}{c}0.006 \\
(0.009)\end{array}$ & & & $\begin{array}{c}0.004 \\
(0.004)\end{array}$ & $\begin{array}{c}0.002 \\
(0.005)\end{array}$ & $\begin{array}{c}0.004 * \\
(0.002)\end{array}$ & $\begin{array}{c}0.016^{*} \\
(0.009)\end{array}$ & $\begin{array}{l}-0.003 \\
(0.006)\end{array}$ & $\begin{array}{c}0.023 * * * \\
(0.008)\end{array}$ \\
\hline Years indep (ln) & $\begin{array}{l}-0.016 \\
(0.038)\end{array}$ & $\begin{array}{c}0.038 \\
(0.094)\end{array}$ & & & $\begin{array}{c}0.006 \\
(0.037)\end{array}$ & $\begin{array}{c}0.021 \\
(0.035)\end{array}$ & $\begin{array}{l}-0.001 \\
(0.020)\end{array}$ & $\begin{array}{l}-0.013 \\
(0.083)\end{array}$ & $\begin{array}{l}-0.083 \\
(0.059)\end{array}$ & $\begin{array}{c}0.114 \\
(0.086)\end{array}$ \\
\hline State history & $\begin{array}{l}-0.236 \\
(0.332)\end{array}$ & $\begin{array}{l}-0.307 \\
(0.510)\end{array}$ & & & $\begin{array}{l}-0.280 \\
(0.333)\end{array}$ & $\begin{array}{c}0.300 \\
(0.367)\end{array}$ & $\begin{array}{c}-0.598^{* *} \\
(0.284)\end{array}$ & $\begin{array}{l}-0.138 \\
(0.652)\end{array}$ & $\begin{array}{l}-0.144 \\
(0.440)\end{array}$ & \\
\hline Democracy & & & & & $\begin{array}{c}0.025^{* * *} \\
(0.009)\end{array}$ & $\begin{array}{l}-0.001 \\
(0.003)\end{array}$ & & & & \\
\hline Protestant $(\%)$ & & & & & & $\begin{array}{c}0.001 \\
(0.003)\end{array}$ & & & & \\
\hline Growth & & & & & & $\begin{array}{l}-0.000 \\
(0.000)\end{array}$ & & & & $\begin{array}{c}0.021 \\
(0.018)\end{array}$ \\
\hline Natural resources & & & & & & $\begin{array}{c}0.026^{* * *} \\
(0.008)\end{array}$ & & & & \\
\hline English colony & & & & & & $\begin{array}{l}-0.107 \\
(0.239)\end{array}$ & & & & \\
\hline Ethnic fract & & & & & & $\begin{array}{l}-0.211 \\
(0.358)\end{array}$ & & & & \\
\hline Linguistic fract & & & & & & $\begin{array}{l}-0.145 \\
(0.395)\end{array}$ & & & & \\
\hline Religious fract & & & & & & $\begin{array}{l}-0.192 \\
(0.338)\end{array}$ & & & & \\
\hline Internal conflict & & & & & & $\begin{array}{l}-0.066 \\
(0.103)\end{array}$ & & & & \\
\hline Lagged DV & & & & & & & & & $\begin{array}{c}0.033 \\
(0.040)\end{array}$ & $\begin{array}{c}0.444 * * * \\
(0.122)\end{array}$ \\
\hline Decade dummies & & & & & & & & & & $\checkmark$ \\
\hline Year dummies & $\checkmark$ & & & & $\checkmark$ & $\checkmark$ & $\checkmark$ & $\checkmark$ & $\checkmark$ & \\
\hline Region dummies & $\checkmark$ & $\checkmark$ & & & $\checkmark$ & $\checkmark$ & $\checkmark$ & $\checkmark$ & $\checkmark$ & \\
\hline Countries & 98 & 98 & 154 & 154 & 98 & 88 & 199 & 98 & 98 & 153 \\
\hline Years/periods (max) & 115 & 1 & 153 & 155 & 115 & 94 & 194 & 115 & 115 & 14 \\
\hline Observations & 6,059 & 98 & 8,753 & 8,753 & 6,004 & 4,766 & 25,178 & 6,059 & 5,863 & 897 \\
\hline $\mathrm{R}^{2}$ (pseudo) & 0.353 & 0.565 & 0.154 & 0.150 & 0.363 & 0.398 & & $(0.163)$ & 0.337 & \\
\hline
\end{tabular}

Notes: Outcome: leadership succession institutionalization index (additive). Country clustered standard errors in brackets. ${ }^{* * *} \mathrm{p}<0.01,{ }^{*} \mathrm{p}<0.05,{ }^{*} \mathrm{p}<0.10$ 
Model 1 in Table 2, the benchmark model, adopts an ordinary least squares (OLS) estimator with errors clustered by country. Since the relationship between population and institutionalization is assumed to be distal, we measure right-side variables two decades prior to the outcome (a 20-year forward lag). As covariates, we include other factors that are plausibly exogenous and might affect a country's political institutions. This includes log-transformed per capita GDP (Bolt \& van Zanden 2014), urbanization (Coppedge et al. 2016; constructed from data drawn from CLIO Infra), years since independence (log-transformed), , state history (Putterman \& Weil 2010), and geographic region dummies. We also include year fixed-effects to account for global trends. Details on sources and coding are contained in Table A1 and descriptive statistics in Table A2.

Model 1 reports a strong, positive relationship between population size and institutionalization, with a t-value of 3.5. Note that by including years since independence as a covariate we aim to model the learning that occurs as a state accrues experience in the task of governing. And, by including a widely used measure of state history - a country's history of "state-ness" extending back to year 0 - we aim to control for possible endogeneity between right- and left-side factors; the correlation reported between population size and institutionalization does not simply reflect that older polities have had more time to grow their populations and to institutionalize their politics.

Figure 2 displays the predicted values of our institutionalization measure for various population sizes, according to Model 1, with covariates set to their sample means. The logged relationship means that variation at the bottom end of the scale has a much greater impact on institutionalization than variation at the top. It also requires a sizeable difference in population to register a significant increase or decrease in institutionalization. However, major differences in size have major effects on levels of political institutionalization. An increase in population from ten thousand to ten million is associated with an increase in our (5-point) institutionalization index of over one point, about one standard deviation. If one wishes to understand why politics 
in Micronesia (pop. $\sim 100,000$ ) is different from politics in the Dominican Republic (pop. $\sim 10$ million) - or, for that matter, in China (pop. $\sim 1.4$ billion) - size is an essential element of that explanation.

Figure 2: Predicted Values

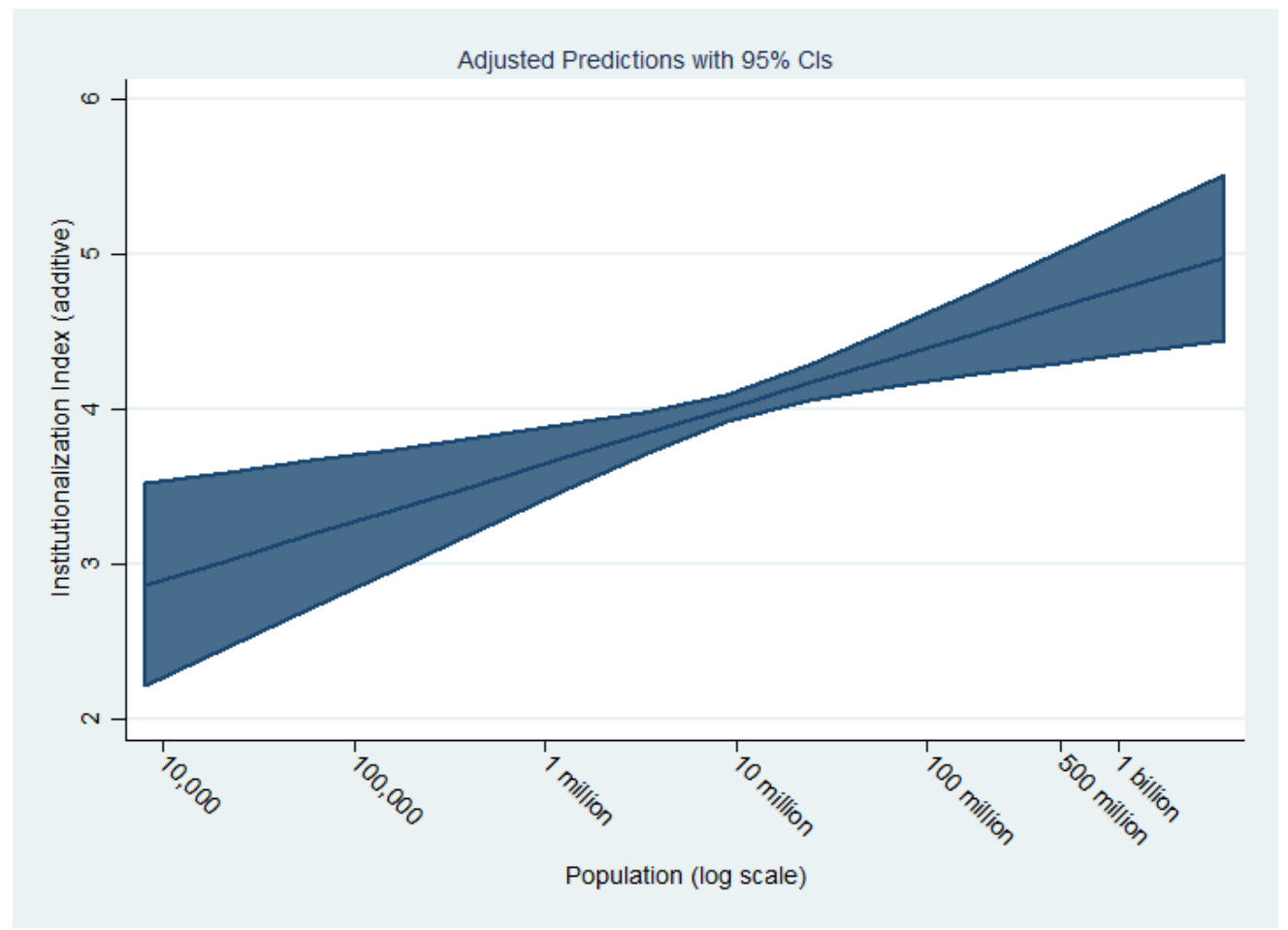

Predicted values from Model 1, Table 2, with covariates set to mean values, surrounded by $95 \%$ confidence interval.

Additional tests in Table 2 offer variations on the benchmark. Model 2 is a single crosssectional analysis in which the outcome is measured in 2000 and population in 1900. All other right-side variables are measured in 2000 to minimize data loss due to poor coverage for these variables in 1900. (We realize that this may introduce post-treatment confounding, as discussed below.) Estimates are virtually identical to the benchmark.

Model 3 reverts to the cross-section time-series format, with right-side variables measured two decades before the outcome. Here, we include only a single covariate - per capita GDP. This minimal specification reduces risks of post-treatment confounding and also provides 
an extremely large sample - 154 countries, observed across up to 153 years, producing nearly 9,000 country-year observations. This model also yields a highly significant, positive coefficient.

Model 4 replicates Model 3 but with dummies representing different levels of population. Specifically, the logged population variable is divided into four quartiles (for observations included in the regression analysis). Cutoffs are therefore roughly equidistant on the logged scale. This provides a simple check of functional form in the benchmark model. Findings show that the estimated coefficients for these dummies (with the first quartile as the reference category) increase in a monotonic, and roughly linear, fashion, suggesting that the logged variable in our benchmark model provides a good fit for the data.

Model 5 adds a control for democracy to the benchmark model, measured with the Polity2 index, which extends back to the $19^{\text {th }}$ century (Marshall, Gurr \& Jaggers 2014). We thus test the possibility that regime-type serves as a common-cause confounder, affecting both size and succession practices. However, the estimated coefficient for population size is identical to the estimate from our benchmark model. Because of this, and the possibility that regime-type might be endogenous to polity size (introducing post-treatment confounding), we do not include Polity 2 in our benchmark specification.

Model 6 is a "kitchen-sink" specification intended to include the various plausible rightside factors that are measurable in a large sample of countries and that might serve as confounders (we discuss models controlling for conflict in the next section). Additional covariates, alongside regime type, include Protestants (as share of the population), per capita GDP growth, natural resource wealth (Haber \& Menaldo 2011), English colonial heritage (Miller 2015), ethnic fractionalization, linguistic fractionalization, and religious fractionalization (from Alesina et al. 2003), and civil war (CLIO-Infra). This fuller specification should mitigate concerns about omitted variable bias. Once again, the estimated coefficient for population is close to the benchmark in size and statistical significance. We also run several alternate specifications that add additional covariates to the ones shown in Model 6. These tests show that the main result is 
stable even when controlling for various measures of instability and geographic features such as land area.

The result is also robust to dropping particular cases, and even sets of anticipated influential countries (such as China, Mexico and Russia/Soviet Union) from the sample. Further, we want to check how sensitive the result is to including observations missing from the benchmark. Thus, Model 7 is the benchmark with missing values imputed using Amelia II (Honaker, King \& Blackwell 2012). This is an important test, since convenience samples, based on data coverage for key variables, might produce biased estimates. We generate 20 imputed datasets, which are used to produce the estimates (average coefficients; imputation-corrected errors). The resulting sample includes 199 countries, observed from 1800-2014 (the final two decades are excluded in the analysis due to the lagged regressors), with more than 25,000 observations - roughly four times the size of our benchmark model. The relationship between population and institutionalization is attenuated, though still weakly significant $(p<0.10)$. Note, however, that most of the imputed data is from prior to World War II, when coverage is scarcer. When the analysis is restricted to the contemporary period, the estimated relationship is much stronger. One may speculate that the imputation process has introduced some sort of bias (due, presumably, to the paucity of data for the historical period) and/or that the relationship of interest is stronger for the contemporary era, an issue we return to below.

Model 8 employs an ordered logit estimator, in accordance with the ordinal scale of the additive institutionalization index. Results are similar to the OLS model, judging by t statistics $(\mathrm{t}=3.5$ for population). Although it might be tempting to interpret the sensitivity of the response across different thresholds, variation across thresholds may be stochastic rather than systematic. For this reason, and for its ease of interpretation, we retain OLS as the benchmark estimator.

Model 9 employs a random effects estimator. Because the focus is now on variation through time (in addition to variation across countries) a lagged dependent variable is included as regressor, along with the usual year fixed-effects. (Exclusion of this lagged variable has little 
impact on the results.) As expected, we find that institutionalization increases as the size of the polity grows.

Model 10 employs a system generalized method of moments (GMM) model, which is regarded as appropriate for studying sluggish variables (Blundell \& Bond 1998). This estimator includes level and differences regressions, and accounts for endogenous regressors by using lags of levels to instrument for differences and lags of differences to instrument for levels. In accordance with standard practice for GMM models with long time-series, we re-code annual data at ten-year intervals, reducing the number of temporal increments - and hence the number of instruments - and allowing for valid identification (following the assumptions of the model). We allow two lags for instrumentation, producing 80 instruments - well below the number of cross-sectional units (153), often regarded as a rule-of-thumb threshold (Roodman 2009). Both population and per capita GDP are treated as endogenous. The AR(2) test rejects autocorrelation in the first differences at the $5 \%$ level $(p=0.06)$ and the Hansen $J$-test $p$-value is 0.28 , suggesting that Model 9 provides consistent estimates. Indeed, the estimated (short-term) effect of population on institutionalization is somewhat stronger than for our benchmark. ${ }^{4}$

\section{Accounting for the endogeneity of population size}

Initial tests, summarized in Table 2, presume that population is exogenous conditional on other factors measured in various models and conditional on the temporal structure of the model (population is lagged two decades behind the outcome). Even so, the assumption of exogeneity may be questioned. Political institutionalization could pave the way for population growth, or

\footnotetext{
${ }^{4}$ Variations in this GMM model - e.g., to controls included or number of lags used for instrumentation - do not affect the main result. The only exceptions we detected relate to altering the variables treated as endogenous, as, e.g., the model treating only population as endogenous returns a statistically insignificant result. However, the coefficient remains high (.17), and the Sargan p-value of .09 suggests that this specification may not satisfy the exclusion restriction.
} 
some unmeasured confounder such as participation in international wars or a general climate of political (in)stability could affect both right and left sides of the model. In Appendix B, we present specifications controlling for various measures of conflict; these show thatthe main result is robust. Additionally, we present results from an instrumental variable specification, using geographical features (land area and agricultural suitability) as instruments. This test also gives similar results to the benchmark.

All these models assume that country borders are exogenous - a fundamental assumption that underlies virtually any analysis, qualitative or quantitative, that employs countries as units. In this circumstance, the assumption bears special consideration since the outcome of interest - political institutionalization - might conceivably affect the shape (and hence the population size) of nation-states.

If such a reverse effect exists, it is unclear whether it might be positive or negative. Less institutionalized polities may pursue more expansionist policies, as personal rule and foreign conquest often run together (Weeks 2012). While many European empires sustained constitutional systems of rule in the home country, these empires subsequently collapsed and are not included in our analysis, which focuses on sovereign countries (excluding foreign colonies or protectorates not fully integrated into the metropole).

Among nation-states in our sample we can distinguish two varieties. Those recognized as sovereign in the nineteenth century generally have long prior histories. For these states, borders are largely fixed over the period of observation. These states developed from a core "ethnos" over many centuries, eventually establishing fixed borders (Smith 1988). A few, like China, absorbed large territories and developed large populations; most, like European states, were more contained. Hence, early states did not usually develop larger territories and the capacity for sustaining larger populations. Only Japan and China are both old and large; other states with long histories are small-to-moderate in size. Nonetheless, we control for state history and length of independence in our analysis. 
A second variety of nation-state enters our sample in the late $19^{\text {th }}$ century or $20^{\text {th }}$ century. These countries are largely the product of colonial demarcations and are, in this sense, exogenous - being imposed from abroad, often in a highly arbitrary fashion. Models $1-2$ in Table 2 center on "old states" while Models 3-4 and 6 include numerous "new states." The fact that estimates of size are fairly consistent suggests that the mode of determining borders does not affect our core finding.

Further tests reported in Table 3 corroborate this conclusion. Model 1 is limited to the past several decades (1970-). With the notable exceptions of the dissolution of the Soviet Union, Czechoslovakia and Yugoslavia, borders were mostly frozen during this period. We also control for institutionalization in 1970, setting upa lagged dependent variable model that investigates changes in institutionalization during a time period in which borders were largely stable. Here, we find a very similar coefficient estimate for log population measured in 1970 as we did for log population measured in 1900 (Model 2, Table 2). Results are not altered when countries from Eastern Europe and the post-Soviet bloc are excluded (see Model 3). 
Table 3: Accounting for endogeneity of borders and populations with limited samples

\begin{tabular}{|c|c|c|c|c|c|}
\hline \multirow{3}{*}{ Sample } & \multicolumn{3}{|c|}{ Cross-section regressions } & \multirow{2}{*}{\multicolumn{2}{|c|}{$\begin{array}{l}\text { Panel regression } \\
\text { Former colonies }\end{array}$}} \\
\hline & \multicolumn{2}{|c|}{ Full } & \multirow{2}{*}{$\begin{array}{c}\text { Soviet/East Europe } \\
\mathbf{3}\end{array}$} & & \\
\hline & 1 & 2 & & 4 & 5 \\
\hline Population (ln) & $\begin{array}{l}0.152^{*} \\
(0.087)\end{array}$ & $\begin{array}{c}0.208^{* * *} \\
(0.069)\end{array}$ & $\begin{array}{c}0.234 * * * \\
(0.069)\end{array}$ & $\begin{array}{c}0.250 * * * \\
(0.08)\end{array}$ & $\begin{array}{c}0.166^{* *} \\
(0.08)\end{array}$ \\
\hline GDP per cap (ln) & $\begin{array}{c}0.055 \\
(0.204)\end{array}$ & $\begin{array}{c}0.249 * * * \\
(0.090)\end{array}$ & $\begin{array}{c}0.234 * * \\
(0.090)\end{array}$ & $\begin{array}{l}0.286^{*} \\
(0.15)\end{array}$ & $\begin{array}{l}0.126 \\
(0.14)\end{array}$ \\
\hline Urbanization & $\begin{array}{c}0.005 \\
(0.009)\end{array}$ & & & $\begin{array}{c}0.017 * * * \\
(0.01)\end{array}$ & \\
\hline Years since independence (ln) & $\begin{array}{c}0.028 \\
(0.106)\end{array}$ & & & $\begin{array}{l}-0.055 \\
(0.11)\end{array}$ & \\
\hline State history & $\begin{array}{l}-0.152 \\
(0.519)\end{array}$ & & & $\begin{array}{l}0.593 \\
(0.63)\end{array}$ & \\
\hline Lagged DV & $\begin{array}{c}0.019 \\
(0.101)\end{array}$ & $\begin{array}{c}0.255^{* * *} \\
(0.095)\end{array}$ & $\begin{array}{c}0.296^{* * *} \\
(0.099)\end{array}$ & & \\
\hline Region dummies & $\checkmark$ & $\checkmark$ & $\checkmark$ & $\checkmark$ & $\checkmark$ \\
\hline Year dummies & & & & $\checkmark$ & $\checkmark$ \\
\hline Observations & 95 & 123 & 114 & 1607 & 2238 \\
\hline $\mathrm{R}^{2}$ (pseudo) & 0.555 & 0.274 & 0.309 & 0.307 & 0.224 \\
\hline
\end{tabular}

Notes: Outcome: institutionalization index (additive) measured in year 2000 and all regressors (including lagged DV) are measured in 1970 for the cross-section regressions. For the panel regressions, country-year is unit of analysis, and the sample is limited to the post-1945 era. The dependent variable is measured 20 years after the independent variables. Country clustered standard errors in brackets. ${ }^{* *} \mathrm{p}<0.01,{ }^{*} \mathrm{p}<0.05,{ }^{*} \mathrm{p}<0.10$

Likewise we can exploit the fact that the borders of many former colonies that became independent after World War II, and particularly in Sub-Saharan Africa, had borders that were imposed in an exogenous fashion, and that have remained more or less fixed since decolonization (with a few exceptions such as Sudan—South Sudan and Ethiopia—Eritrea).We utilize this feature of history, limiting the sample to former colonies that became independent after World War II in Models 4 and 5. Given the longer time frame, we return to our panel format (DV forward-lagged by 20 years), including year dummies in addition to region dummies and benchmark covariates. Model 4 reports the benchmark result and Model 5 reports a sparse model controlling only for income level. In both cases, population size is statistically significant, and the point estimates are higher than for the benchmark on the full sample. 
In sum, population size predicts institutionalization decades later, even when holding initial institutionalization constant and limiting the sample to a period in which borders are fairly constant, or where borders are arbitrarily assigned.

A final potential confounder is war. States involved in continual violent conflict may become larger and more institutionalized (Tilly 1992), influencing both sides of our causal model. To test this proposition we include various measures of interstate conflict and military capacity as covariates in the benchmark specification. Results, summarized in Table B2, show that controlling for conflict or military capacity has little impact on the main effect.

\section{Alternate Measures}

While we regard our additive index as highly plausible, we recognize that there are other ways this diffuse concept could be operationalized. In this section, we investigate alternative methods of aggregation and disaggregation.

Our primary index is additive across the five indicators, generating a scale from $0-5$. To assure that results are not contingent on any particular element, we produce reduced versions, i.e., five indices where each of the indicators is dropped, seriatim. Then we re-run the benchmark model (Model 1, Table 2). These tests, reported in Appendix Table E1, reveal that the relationship between population and our additive index of institutionalization is stable and robust to the omission of any single indicator.

A different approach to aggregation employs principal components analysis (PCA). Here, the first component explains only $36.0 \%$ of the variance. However, fitting a linear model onto binary indicators is problematic. When the same analysis is conducted with polychoric factor analysis, designed to account for ordered categorical measures (Holgado-Tello et al. 2010), the first factor accounts for $47.4 \%$ of the variance. Nonetheless, the bivariate correlation between the first components produced by PCA and polychoric analysis is nearly perfect (0.9991). We adopt the more familiar PCA as the basis for our second index, and provide two tests. The first 
replicates Model 1 in Table 2 (our benchmark). The second replicates Model 3 in Table 2 (our minimal specification, allowing for a much larger sample). Results, shown in Appendix Table E1, are consistent with those for the additive index.

A third index treats each of the foregoing attributes as necessary conditions of the fully realized concept, i.e., where leadership succession is fully institutionalized. Thus, we code each polity-year as 1 if (and only if) it satisfies all five conditions, and 0 otherwise. Roughly $2 / 3$ of the sample receives a 0 , exemplifying the higher threshold imposed by this approach. Results are again robust.

A final approach regards tenure in office - one of the five original indicators - as the sole measure of political institutionalization. Tenure is here measured as number of years an executive has held office continuously. (Transforming this number by the natural logarithm does little to change results.) The variable has a minimum value of 1 (year), maximum of 68 , mean of 7.4 , and standard deviation of 8.4.

The rationale for this measure builds on the assumption that most executives would prefer to retain office rather than retire to private life. Likewise, concentration of decisionmaking power in the hands of the leader typically increases during the leader's tenure (Abramson \& Rivera 2016; Svolik 2012). A timely departure thus indicates that the executive is unable to preserve his/her power and is therefore subject to institutional constraints. By contrast, long tenure in office suggests that there are no rules limiting executive tenure or that those rules have been abrogated.

The advantage of this factual measure is that it does not depend upon any coder judgments. The disadvantage is that it tells us nothing about the circumstances of appointment and removal. Nonetheless, tests of the benchmark and reduced specifications indicate that population is also a strong predictor of tenure in office. In larger countries, executives experience shorter terms. In sum, the relationship between population size and institutionalization is not 
contingent upon arbitrary decisions about how to aggregate various elements of a successionbased measure of institutionalization.

\section{Conclusions}

Studies of institutions are ubiquitous. Studies of institutionalization are less common, perhaps because the concept is so difficult to measure. How do we know when rules have gained precedence over rulers? We have proposed an approach that centers on leadership succession.

This approach offers several advantages. First, while other aspects of leadership behavior are often shrouded in mystery, the moment of leadership transition is relatively transparent - or becomes so over time as the historical record is pieced together. Second, because all political systems, regardless of their formal or informal rules, involve leadership transitions, this element of politics is universal. Finally, practices of leadership selection and de-selection may signal the extent to which executive power is personalized or institutionalized, more generally. When power is institutionalized, leaders typically exit office at fairly regular intervals without violating constitutional rules. When power is personalized, leaders cling on to power - often violating formal-constitutional term limits - before they are ultimately removed, often by nonconstitutional means. Drawing on data from Archigos, we construct an index of institutionalization of leadership succession that covers most sovereign states from the midnineteenth century to the present.

We also propose an argument, centering on the size of political communities, to help explain why countries vary in terms of institutionalization of leadership succession. In larger polities, we argue, leadership succession is likely to be more highly institutionalized, as both incumbent and non-incumbent elites are more likely to view such institutionalization to be in their longer-term interest. Further, citizens have stronger incentives to demand institutionalized succession, as monitoring and coordination issues increase with polity size. We subject the 
argument to a wide variety of empirical tests, finding a robust relationship between size and institutionalization.

Questions may be raised about the generalizability of this argument. Split-sample tests (see Table C1) suggest that the relationship obtains in democracies and autocracies, although results are stronger and more robust in autocracies. We have not attempted to test the relationship within sub-types of these broad categories (e.g., Hadenius \& Teorell 2007). It seems plausible that the relationship between size and institutionalization might vary across regions of the world. However, any test of this sort stumbles against a small-sample problem, making it difficult to distinguish causal and purely stochastic patterns in the data. What we do find (Table C1) is that the global relationship is robust to the exclusion of various regions of the world, i.e., the observed pattern is not driven by any single region.

While the main hypothesis is tested across a two-century period it is not clear whether the impact of population is constant across this period. The empirical picture is ambiguous because the sample of nation-states varies across time. Much of the world was not organized into sovereign states prior to the mid-twentieth century. Additionally, nation-states were limited in population size in the nineteenth century, truncating variation along the dimension of interest. Nonetheless, as we indicated in Section I, there are reasons to suppose that the impact of population on institutionalization may have grown over time, being stronger today than it was a century ago. This is confirmed in split-sample tests reported in Appendix C. We regard this as a signpost for future enquiry.

One may also speculate about the applicability of our measure and our theory to other organizations. Note that leadership succession is a critical moment for tribes (de Pina-Cabral \& de Lima 2000; Goody 1966), firms and non-profit organizations (Friedman 2011; Giambatista, Rowe \& Riaz 2005; Kesner \& Sebora 1994; Ocasio 1999), political parties (Laing \& t’ Hart 2011), and criminal syndicates (de Pina-Cabral \& de Lima 2000). Accordingly, one could develop 
measures of institutionalization that focus on moments of leadership transition and test whether a similar relationship between size and institutionalization exists in these very different contexts.

\section{References}

Abramson, Scott, Carlos Velasco Rivera. 2016. "Time Is Power: The Noninstitutional Sources of Stability in Autocracies." The Journal of Politics 78.4: 1279-1295.

Alesina, Alberto, Arnaud Devleeschauwer, William Easterly, Sergio Kurlat, Romain Wacziarg. 2003. "Fractionalization." Journal of Economic Growth 8:2, 155-94.

Alvarez, Mike, Jose A. Cheibub, Fernando Limongi, Adam Przeworski. 1996. “Classifying Political Regimes." Studies in Comparative International Development 31:2, 3-36.

Bienen, Henry, Nicolas Van de Walle. 1991. Of time and power: leadership duration in the modern world. Stanford: Stanford University Press.

Blundell, Richard, Stephen Bond. 1998. "Initial Conditions and Moment Restrictions in Dynamic Panel Data Models." Journal of Econometrics 87:1, 115-143.

Boix, Carles, Milan W. Svolik. 2013. "The foundations of limited authoritarian government: Institutions, commitment, and power-sharing in dictatorships." Journal of Politics 75.2: 300316.

Bolt, Jutta, Jan Luiten van Zanden. 2014. “The Maddison Project: Collaborative Research on Historical National Accounts." The Economic History Review 67:3, 627-651.

Bratton, Michael, Nicholas Van de Walle. 1997. Democratic experiments in Africa: Regime transitions in comparative perspective. Cambridge: Cambridge University Press.

Bunce, Valerie. 1981. Do New Leaders Make a Difference? Executive Succession and Public Policy under Capitalism and Socialism. Princeton: Princeton University Press.

Calvert, Peter (ed.). 1987. The Process of Political Succession. London: Macmillan. 
Chenoweth, Erica, Maria J. Stephan. 2011. Why civil resistance works: The strategic logic of nonviolent conflict. New York: Columbia University Press

Collier, Ruth Berins. 1999. Paths toward democracy: The working class and elites in Western Europe and South America. Cambridge: Cambridge University Press.

Coppedge, Michael, John Gerring, Staffan I. Lindberg, Jan Teorell, David Altman, Michael Bernhard, M. Steven Fish, Adam Glynn, Allen Hicken, Carl Henrik Knutsen, Kelly McMann, Daniel Pemstein, Megan Reif, Svend-Erik Skaaning, Jeffrey Staton, Eitan Tzelgov, Yi-ting Wang, Brigitte Zimmerman. 2016. "Varieties of Democracy (V-Dem) Dataset. v.5.” Varieties of Democracy (V-Dem) Project.

Dahl, Robert A., Edward R. Tufte. 1973. Size and Democracy. Stanford: Stanford University Press. de Pina-Cabral, João, Antónia Pedroso de Lima (eds). 2000. Elites: Choice, Leadership and Succession. Oxford: Berg.

Duindam, Jeroen. 2015. Dynasties: A Global History of Power, 1300-1800. Cambridge: Cambridge University Press.

Ebrey, Patricia. 2006. "Succession to High Office: The Chinese Case.” In David R. Olson and Michael Cole (eds), Technology, Literacy, and the Evolution of Society: Implications of the Work of Jack Goody (Erlbaum) 49-71.

Ezrow, Natasha M., Erica Frantz. 2011. "State Institutions and the Survival of Dictatorships." Journal of International Affairs 65:1, 1-13.

Frantz, Erica, Elizabeth A. Stein. 2017. "Countering Coups: Leadership Succession Rules in Dictatorships." Comparative Political Studies 50:7, 935-962.

Friedman, Stewart D. 2011. Leadership Succession. Transaction.

Giambatista, Robert C., W. Glenn Rowe, Suhaib Riaz. 2005. "Nothing Succeeds like Succession: A Critical Review of Leader Succession Literature since 1994.” The Leadership Quarterly 16:6, 963-991. 
Goemans, Hein E., Kristian Skrede Gleditsch, Giacomo Chiozza. 2016. “ARCHIGOS A Data

Set on Leaders 1875-2015, Version 4.1.” (February 28). Downloaded (2016 07 16):

http://privatewww.essex.ac.uk/ ksg/papers/Archigos-27-Feb-2016.pdf

Goody, Jack. 1966. Succession to High Office. Cambridge: Cambridge University Press.

Govea, R. M., J. D. Holm. 1998. "Crisis, violence and political succession in Africa." Third World Quarterly 19, 129-148.

Haber, Stephen, Victor Menaldo. 2011. “Do Natural Resources Fuel Authoritarianism? A

Reappraisal of the Resource Curse." American Political Science Review 105:1, 1-26.

Hadenius, Axel, Jan Teorell. 2007. "Pathways from Authoritarianism.” Journal of Democracy 18:1, 143-156.

Hegre, Håvard, Nicholas Sambanis. 2006. “Sensitivity Analysis of Empirical Results on Civil War Onset." Journal of Conflict Resolution 50:4, 508-535.

Holgado-Tello, Francisco Pablo, Salvador Chacón-Moscoso, Isabel Barbero-García, Enrique Vila-Abad. 2010. "Polychoric versus Pearson correlations in exploratory and confirmatory factor analysis of ordinal variables." Quality \& Quantity 44, 153-166.

Honaker, James, Gary King, Matthew Blackwell. 2011. “Amelia II: A Program for Missing Data." Journal of Statistical Software 45:1, 1-47.

Houle, Christian. 2009. "Inequality and democracy: Why inequality harms consolidation but does not affect democratization." World Politics 61:4, 589-622.

Huang, Jing. 2008. "Institutionalization of Political Succession in China: Progress and Implications" In Li Cheng (ed), China's Changing Political Landscape: Prospects for Democracy (Brookings Institution Press).

Jones, Benjamin F., Benjamin A. Olken. 2005. 'Do Leaders Matter? National Leadership and Growth since World War II.” Quarterly Journal of Economics 120:3, 835-64.

Jones, Benjamin F., Benjamin A. Olken. 2009. "Hit or Miss? The Effect of Assassinations on Institutions and War." American Economic Journal: Macroeconomics 1:2, 55-87. 
Kesner, I.F., T.C. Sebora. 1994. “Executive Succession: Past, Present and Future.” Journal of Management 20:2, 327-372.

Kokkonen, Andrej, Anders Sundell. 2014. "Delivering stability: Primogeniture and autocratic survival in European monarchies 1000-1800.” American Political Science Review 108:2.

Kurrild-Klitgaard, P. 2000. "The constitutional economics of autocratic succession." Public Choice 103(1-2): 63-84.

Kurrild-Klitgaard, P. 2004. "Autocratic succession." In C.K. Rowley \& F. Schneider (eds) The Encyclopedia of Public Choice. Springer, Boston, 358-362.

Magaloni, Beatriz. 2006. Voting for Autocracy: Hegemonic Party Survival and its Demise in Mexico. New York: Cambridge University Press.

Marshall, Monty, Ted Gurr, Keith Jaggers. 2014. Polity IV project: Dataset users' manual. http://www.systemicpeace.org/inscr/p4manualv2013.pdf

Mendoza, Ronald U., et al. 2012. "Inequality in democracy: Insights from an empirical analysis of political dynasties in the 15th Philippine Congress." Philippine Political Science Journal 33.2: 132145.

Michalopoulos, Stelios. 2012. “The Origins of Ethnolinguistic Diversity.” American Economic Review 102:4,1508-1539.

Miller, Alice L. 2008. "Institutionalization and the changing dynamics of Chinese leadership politics." China's Changing political landscape: Prospects for democracy (Washington: Brookings) 61-79.

Miller, Michael K. 2012. 'Economic Development, Violent Leader Removal, and Democratization.” American Journal of Political Science 56:4, 1002-1020.

Miller, Michael K. 2015. "Democratic Pieces: Autocratic Elections and Democratic Development since 1815”. British Journal of Political Science 45:3, 501-530.

Ocasio, W. 1999. "Institutionalized action and corporate governance: The reliance on CEO rules of succession." Administrative Science Quarterly 44:2, 384-403. 
Przeworski, Adam. 1991. Democracy and the market: Political and economic reforms in Eastern Europe and Latin America. Cambridge, MA: Cambridge University Press.

Putterman, Louis, David N. Weil. 2010. "Post-1500 Population Flows and the Long-Run

Determinants of Economic Growth and Inequality." Quarterly Journal of Economics 125:4, 162782.

Querubin, Pablo. 2016. "Family and Politics: Dynastic Persistence in the Philippines." Quarterly Journal of Political Science 11:2, 151-181.

Roodman, David. 2009. "A Note on the Theme of too many Instruments." Oxford Bulletin of Economics and Statistics 71:1, 135-158.

Skaaning, Svend-Erik, John Gerring, Henrikas Bartusevičius. 2015. “A Lexical Index of Electoral Democracy." Comparative Political Studies 48:12 (October) 1491-1525.

Smith, Anthony D. 1988. The Ethnic Origins of Nations. Oxford: Blackwell.

Stasavage, David. 2010. "When distance mattered: geographic scale and the development of European representative assemblies." American Political Science Review 104.4: 625-643.

Stasavage, David. 2011. States of Credit: Size, Power, and the Development of European Polities. Princeton: Princeton University Press.

Svolik, Milan W. 2012. The Politics of Authoritarian Rule. Cambridge: Cambridge University Press.

't Hart, Paul, John Uhr (eds). 2011. How Power Changes Hands: Transition and Succession in

Government. Palgrave Macmillan.

Tilly, Charles. 1992. Coercion, Capital, and European States, AD 990-1992. Cambridge, MA: Blackwell

Treisman, Daniel. 2015. "Income, Democracy, and Leader Turnover”. American Journal of Political Science. 59:4, 927-942.

Tullock, Gordon. 1987. Autocracy. Dordrecht: Kluwer.

Walter, Barbara F. 2009. "Bargaining failures and civil war." Annual Review of Political Science 12: 243-261. 
Weber, Max. 1961. From Max Weber: Essays in Sociology, ed. Hans Gerth \& C. Wright Mills. London: Routledge \& Paul.

Weeks, Jessica. 2012. "Strongmen and Straw Men: Authoritarian Regimes and the Initiation of International Conflict". American Political Science Review 106:2, 326-347.

Weidmann, Nils B., Doreen Kuse, Kristian Skrede Gleditsch. 2010. "The Geography of the International System: The CShapes Dataset.” International Interactions 36:1, 86-106.

Wolford, Scott. 2016. “Wars of Succession.” International Interactions. Online First.

Zeng, Jinghan. 2014. "Institutionalization of the authoritarian leadership in China: a power succession system with Chinese characteristics?" Contemporary Politics 20.3: 294-314. 
Appendix A: Data Description 
Table A1: Variable Definitions

\section{Base-level indicators of institutionalization}

Regular Exit (e_exit_1_regular). Coded 1 if current leader exits office through regular, constitutional processes. Coded 0 if head of state ("leader") dies of natural causes while in power, retires due to ill health, loses office as a result of suicide, loses power through irregular means, or is deposed by another state. Source: Archigos (Goemans et al. 2016).

Post-office punishment (e_posttenurefate_1_OK_nomiss). Coded 0 if a leader is exiled, imprisoned (including house arrest), or killed during the year following his/her departure from office. Coded 1 if none of the foregoing conditions apply. Source: Archigos (Goemans et al. 2016).

Regular Entry (e_entry_1_regular). Coded 0 if a leader gains power by foreign imposition or other irregular/extraconstitutional process. Coded 1 if leader gains power through regular/constitutional processes. Source: Archigos (Goemans et al. 2016).

Nepotism (e_nepotism). Coded 1 if a leader has a kin-relation to any previously serving leader, 0 otherwise. The inverse of this dummy variable is used for constructing the institutionalization indices. Source: Archigos (Goemans et al. 2016).

Tenure, dichotomous (tenure_dich). Coded 1 if a leader is in office between 0 and 10 years, and 0 if longer than 10 years. Source: Archigos (Goemans et al. 2016).

Tenure (e_tenure). The number of years a leader has served continuously. Source: Archigos (Goemans et al. 2016).

\section{Predictors of institutionalization}

Population, $\ln$ (e_mipopula_ln). Number of permanent residents in a country, transformed by the natural logarithm. Missing data within a time-series is interpolated using a linear model. Source: Clio Infra (clio-infra.eu), drawing on Goldewijk, Beusen, Janssen (2010), History Database of Global Environment (www.pbl.nl/hyde).

GDPpc, $\ln$ (e_migdppc_ln). Gross domestic product per capita, transformed by the natural logarithm. Source: Maddison Project (Bolt \& van Zanden 2014).

Urbanization (e_urban). Ratio of urban population to total population. Source: V-Dem (Coppedge et al. 2015), constructed from data from CLIO Infra (clio-infra.eu).

Years since independence, $\ln$ (yrs_since_indep_ln). Number of years since a country became independent (internationally recognized as sovereign), transformed by the natural logarithm. Source: Authors' coding.

State history (Statehistn01). For each country, the history of the territory within its current borders are coded at 50-year intervals back to 1 C.E. Dimensions include (a) the existence of government above the tribal level; (b) whether the government is locally based or foreign, and (c) how much of the territory of the modern country was ruled by the main government. Each 50-year period is discounted by a factor of 1 percent. Source: Putterman \& Weil (2010).

GDPpc growth (e_migdpgro). Annual growth rate of GDP per capita. Source: Maddison Project (Bolt \& van Zanden 2014).

Natural resources (e_Total_Resources_Income_PC). The aggregated real value of a country's petroleum, coal, natural gas, and metals production, understood as a share of total population. Source: Haber \& Menaldo (2011).

Democracy (Polity2). A weighted additive aggregation procedure across five sub-components: competitiveness and openness of executive recruitment, competitiveness and regulation of political participation, and constraints on the chief executive. Source: Polity IV database (Marshall, Gurr \& Jaggers 2014).

English colony (e_Britcolony). Dummy coding whether a country was (or is) an English colony. Source: Miller (2015)

Ethnic fractionalization (al_ethnic). The probability that two randomly chosen individuals within a society are members of different ethnic groups, calculated with the Herfindahl index. Source: Alesina et al. (2003).

Linguistic fractionalization (al_language). The probability that two randomly chosen individuals within a society are members of different linguistic groups, calculated with the Herfindahl index. Source: Alesina et al. (2003).

Religious fractionalization (al_religion). The probability that two randomly chosen individuals within a society are members of different religious groups, calculated with the Herfindahl index. Source: Alesina et al. (2003). 
Table A2: Descriptive statistics

\begin{tabular}{|lrrrrr|}
\hline Variable & \multicolumn{1}{c}{$\boldsymbol{N}$} & Mean & \multicolumn{1}{c|}{ Std. Dev. } & \multicolumn{1}{c|}{ Min. } & \multicolumn{1}{c|}{ Max. } \\
\hline Additive index & 13853 & 3.578 & 1.298 & 0.000 & 5.000 \\
\hline PCA index & 13853 & 0.000 & 1.341 & -3.464 & 1.482 \\
\hline Binary index & 13853 & 0.328 & 0.469 & 0.000 & 1.000 \\
\hline Tenure & 13896 & 7.426 & 8.442 & 1.000 & 68.000 \\
\hline Population (In) & 23328 & 14.669 & 2.270 & 7.224 & 21.009 \\
\hline GDP per cap (ln) & 13200 & 7.770 & 1.002 & 5.315 & 10.667 \\
\hline Urbanization & 11703 & 32.630 & 24.142 & 0.000 & 100.000 \\
\hline Years independent (ln) & 41605 & 1.647 & 2.286 & 0.000 & 7.574 \\
\hline State history & 19234 & 0.377 & 0.278 & 0.012 & 0.978 \\
\hline GDP per capita growth & 12789 & 1.871 & 6.378 & -61.493 & 86.946 \\
\hline Natural resources & 10646 & 595.412 & 3228.968 & 0.000 & 81161.85 \\
\hline Democracy (Polity2) & 15903 & -0.453 & 7.035 & -10.000 & 10.000 \\
\hline English colony & 15350 & 0.186 & 0.389 & 0.000 & 1.000 \\
\hline Ethnic fractionalization & 19514 & 0.437 & 0.258 & 0.000 & 0.930 \\
\hline Linguistic fractionalization & 19891 & 0.387 & 0.284 & 0.002 & 0.923 \\
\hline Religious fractionalization & 21267 & 0.429 & 0.234 & 0.002 & 0.860 \\
\hline
\end{tabular}




\section{Appendix B: Additional Tests}

In the paper we discussed tests trying to check whether our results might be driven by institutionalization affecting polity size (through border changes), rather than the other way around. These tests draw on the notion that international-system factors have contributed to borders being fairly stable globally in specific periods of time. We also reported GMM models in the paper that explicitly modelled population size as endogenous.

In this appendix, we will apply two different approaches. First, in Table B1, we present results where we try to account for various forms of conflict, by adding different controls to the benchmark specification. The broader climate of conflict and instability might be expected to affect both the institutionalization of leader succession as well as population. However, the tests reported in Table B1 does not show any evidence of this, even though we try out a broad set of indicators tapping into conflict as well as military capabilities (see also Table 2 on internal conflict).

Table B1: Controlling for interstate conflict and measures of military capabilities

\begin{tabular}{|c|c|c|c|c|}
\hline & (1) & (2) & (3) & (4) \\
\hline Population (ln) & $\begin{array}{c}0.134 * * \\
(0.05)\end{array}$ & $\begin{array}{c}0.173 * * * \\
(0.05)\end{array}$ & $\begin{array}{c}0.172^{* * * *} \\
(0.05)\end{array}$ & $\begin{array}{c}0.225^{* * *} \\
(0.05)\end{array}$ \\
\hline GDP per cap (ln) & $\begin{array}{c}0.345^{* * *} \\
(0.10)\end{array}$ & $\begin{array}{c}0.344^{* * *} \\
(0.11)\end{array}$ & $\begin{array}{c}0.360^{* * *} \\
(0.11)\end{array}$ & $\begin{array}{c}0.392 * * * \\
(0.10)\end{array}$ \\
\hline Urbanization & $\begin{array}{l}0.005 \\
(0.00)\end{array}$ & $\begin{array}{l}0.005 \\
(0.00)\end{array}$ & $\begin{array}{l}0.006 \\
(0.00)\end{array}$ & $\begin{array}{l}0.005 \\
(0.00)\end{array}$ \\
\hline Years indep (ln) & $\begin{array}{l}-0.013 \\
(0.04)\end{array}$ & $\begin{array}{l}-0.024 \\
(0.05)\end{array}$ & $\begin{array}{l}-0.011 \\
(0.04)\end{array}$ & $\begin{array}{l}-0.007 \\
(0.04)\end{array}$ \\
\hline State history & $\begin{array}{l}0.161 \\
(0.36)\end{array}$ & $\begin{array}{l}-0.050 \\
(0.41)\end{array}$ & $\begin{array}{l}-0.265 \\
(0.34)\end{array}$ & $\begin{array}{l}-0.283 \\
(0.34)\end{array}$ \\
\hline International conflict (Clio-Infra) & $\begin{array}{l}-0.067 \\
(0.10)\end{array}$ & & & \\
\hline Interstate conflict (UCDP/PRIO) & & $\begin{array}{l}0.030 \\
(0.04)\end{array}$ & & \\
\hline Military size (COW) & & & $\begin{array}{l}-0.101 \\
(0.09)\end{array}$ & \\
\hline Military capability (COW) & & & & $\begin{array}{c}-3.292^{* * *} \\
(1.10)\end{array}$ \\
\hline Year dummies & $\checkmark$ & $\checkmark$ & $\checkmark$ & $\checkmark$ \\
\hline Region dummies & $\checkmark$ & $\checkmark$ & $\checkmark$ & $\checkmark$ \\
\hline Countries & 91 & 98 & 98 & 98 \\
\hline Years/periods (max) & 94 & 48 & 125 & 136 \\
\hline Observations & 5076 & 3748 & 5478 & 5841 \\
\hline $\mathrm{R}^{2}$ (pseudo) & 0.367 & 0.410 & 0.377 & 0.368 \\
\hline
\end{tabular}

Notes: Estimator: Ordinary Least Squares. Outcome: institutionalization index (additive) measured in year $t+20$. All regressors are measured in year $t$. Country clustered standard errors in brackets. ${ }^{* * *} \mathrm{p}<0.01,{ }^{* *} \mathrm{p}<0.05,{ }^{*} \mathrm{p}<0.10$ Sources: COW (Sarkees \& Wayman 2010), CLIO-Infra (Brecke 2013), UCDP/PRIO (Gleditsch et al. 2002). 
Next we try out a two stage least squares (2SLS) specification. Given the ever-present issue of ensuring that the exclusion restriction is not violated - something that is difficult to do with a high degree of certainty when addressing complex relationships such as ours - we want to emphasize that this model is not intended as a magic bullet for causal identification but rather as an additional robustness test. In common with all IV models where the instrument is not randomized, this one depends upon assumptions that are not amenable to empirical tests. We regard these assumptions as reasonable, but not beyond reproach.

The instruments that we use include land area (the total territory of a country, transformed by the natural logarithm [Weidmann, Kuse \& Gleditsch 2010]), and agricultural suitability, a variable that combines climate, soil, and other properties assumed to condition agricultural productivity (Michalopoulos 2012). Together, these factors predict nearly fifty percent of the variation in population (logged), which fits with a common-sense story in which demography responds, over time, to the amount of land available and the carrying capacity of that land.

The IV model, reported in Table B2, follows the benchmark, with nearly identical covariates. The only alteration is the replacement of annual dummies with decade dummies, required in order to render the model tractable. We employ a two-stage least squares estimator, though results are virtually identical when estimating a limited-information maximum likelihood model. As indicated above, Land area and Agricultural suitability are strong instruments, and the first-stage results are reported in Column 1. Both Land area and Agricultural suitability are highly significant, and F-tests also suggest that they pass any conventional threshold for being considered as strong instruments. Reassuringly, the second-stage results from the IV model, reported in Column 2, show familiar estimates for the impact of population on institutionalization. Indeed, coefficients and standard errors are virtually identical to the benchmark model.

Concerning the exclusion restriction, the Hansen J-test p-value is 0.23 , suggesting that it may hold. Further, we find it theoretically plausible to suppose that geographic features are not amenable to political manipulation (though one must be cautious about the issue of country borders, as discussed below). Insofar as these factors affect institutionalization, we imagine that these effects run through population or through other factors measured in the model. If, for example, land area and agricultural suitability affects institutionalization through enhancing economic development or early state development, the exclusion restriction should still be satisfied since we control for these factors, as well as for regional effects. 
Table B2: Instrumental Variable Analysis

\begin{tabular}{|lcc|}
\hline Stage & First & Second \\
Sample & Full & Full \\
Lag (years) & 20 & 20 \\
Model & $\mathbf{( 1 )}$ & $\mathbf{( 2 )}$ \\
Population (ln) & & $0.179^{* * *}$ \\
& & $(0.058)$ \\
Land area (ln) & $0.624^{* * *}$ & \\
& $(0.065)$ & \\
Agricultural suitability & $1.408^{* * *}$ & \\
& $(0.479)$ & \\
GDP per cap (ln) & $-0.243^{*}$ & $0.405^{* * *}$ \\
& $(0.138)$ & $(0.108)$ \\
Urbanization & $0.021 * * *$ & 0.004 \\
& $(0.006)$ & $(0.005)$ \\
Years indep (ln) & 0.037 & -0.011 \\
& $(0.043)$ & $(0.038)$ \\
State history & $1.000^{* * *}$ & -0.315 \\
& $(0.452)$ & $(0.345)$ \\
Decade dummies & $\checkmark$ & $\checkmark$ \\
Region dummies & $\checkmark$ & $\checkmark$ \\
Countries & 94 & 94 \\
Years/periods (max) & 115 & 115 \\
Observations & 5,951 & 5,951 \\
R² (pseudo) & 0.7881 & 0.347 \\
F & 28.77 & \\
& & \\
\end{tabular}

Notes: Outcome: institutionalization index (additive). Estimator: two stage least squares regression. Country clustered standard errors in brackets. ${ }^{* * *} \mathrm{p}<0.01,{ }^{* *} \mathrm{p}<0.05, * \mathrm{p}<0.10$ 


\section{Appendix C: Split-sample Tests}

In Table C1, we subdivide the population of interest so as to test the relationship between population and institutionalization on chosen subsets of the global sample. For this approach to be informative the full sample should be as extensive as possible and not subject to arbitrary exclusions imposed by list-wise deletion of observations with missing data. Thus, we employ the minimal specification shown in Model 3 of Table 2, offering a full sample of 154 countries, 153 years, and 8,753 observations.

We begin by distinguishing regime types. Autocracies are defined here as regimes with no elections, noncompetitive elections, or legislative elections only - operationalized by scores of 0 3 on the Lexical index of electoral democracy (Skaaning, Gerring \& Bartusevičius 2015). Democracies are defined as regimes with minimally competitive, multiparty elections for the legislature and the executive, with or without universal suffrage - scores of 4-6 on the Lexical index. Dividing observations in this fashion generates sub-samples of roughly equal size. Comparing Models 1 and 2 we find that population is associated with institutionalization in both democratic and non-democratic contexts, and the estimates are remarkably close. This pattern persists even if we define democracy in a somewhat more demanding fashion, e.g., as polities with a score of at least 5 on the Lexical scale. It also persists if we define regimes using the Polity 2 index using cutoffs at 0 or 5 on that index (which extends from -10 to +10 ). These results, coupled with our earlier test of Polity2 as a covariate in Model 5, Table 2, suggest that the impact of population on institutionalization is not contingent on regime type. Larger polities are more institutionalized whether they are democratic or autocratic. Yet, we note that when we add the full set of covariates to the split-sample specifications in C1, the coefficient remains large and robust for autocracies, whereas it is no longer significant at conventional levels for democracies.

A second set of tests in Table C1 compares results for two periods - a historical sample, extending from 1840 to 1960 (Model 3), and a contemporary sample extending from 1960 to 2012 (Model 4). This generates two sub-samples with similar numbers of observations but very different numbers of countries and years. Results show that the relationship between population and institutionalization is positive and statistically significant $(\mathrm{p}<0.10)$ in both eras, though considerably stronger in the contemporary era - bearing out our speculative hypothesis about the scope-conditions of the theory (Section I).

A final set of tests in Table $\mathrm{C} 1$ removes various regions of the world from the sample sequentially, as indicated in the headings to columns 5-14. All of these sub-sample tests corroborate our basic finding - population is associated with higher institutionalization. Generally, the estimated coefficient from these sub-sample tests is quite close to the estimate obtained with the full sample. Only the removal of countries situated in the Middle East and North Africa (MENA) has a strong attenuating effect, though it also retains significance $(p<0.10)$. It is tempting to construct a causal story about the uniqueness of the MENA region to explain the attenuated effect that appears when this region is omitted. However, when we replicate this sub-sample test with the benchmark specification (including additional covariates) the removal of MENA countries has virtually no impact on estimates for the key variable of theoretical interest. This suggests that the apparent distinctiveness of the MENA region may be an artifact of model specification.

In any case, the tests depicted in Table C1 suggest that the positive relationship between population and institutionalization is persistent across regime-types, throughout the modern era, and throughout the world. As our discussion suggests, this does not mean that the effect is uniform across all contexts. Moreover, the strength of the relationship may be mediated by many background factors, of which we have examined only a few. When testing a theory with heterogeneous units such as nation-states one can expect a fair degree of causal heterogeneity. Although it would be interesting to delve more deeply into these contextual factors, and potential scope-conditions, we leave this project for future research. 
Table C1: Split-sample Tests

\begin{tabular}{|c|c|c|c|c|c|c|c|c|c|c|c|c|c|c|}
\hline \multirow[b]{2}{*}{ Sample } & \multicolumn{2}{|c|}{ REGIMES } & \multicolumn{2}{|c|}{ ERAS } & \multicolumn{10}{|c|}{ EXCLUDED REGIONS } \\
\hline & $\begin{array}{c}\text { Autocracies } \\
\text { (1) }\end{array}$ & $\begin{array}{c}\text { Democracies } \\
\text { (2) }\end{array}$ & $\begin{array}{c}1840-1960 \\
\text { (3) }\end{array}$ & $\begin{array}{c}1960-2012 \\
\text { (4) }\end{array}$ & $\begin{array}{l}\text { E. Europe } \\
\text { Central Asia } \\
\text { (5) }\end{array}$ & $\begin{array}{c}\text { Eatin } \\
\text { Ameriea } \\
\text { (6) }\end{array}$ & $\begin{array}{l}\text { MENA } \\
(7)\end{array}$ & $\begin{array}{l}\text { Afriea } \\
(8)\end{array}$ & $\begin{array}{l}\text { W. Europe } \\
\text { N.America } \\
\text { (9) }\end{array}$ & $\begin{array}{l}\text { East } \\
\text { Asia } \\
(10)\end{array}$ & $\begin{array}{l}\text { Southest } \\
\text { Asia } \\
\text { (11) }\end{array}$ & $\begin{array}{l}\text { South } \\
\text { Asia } \\
(12)\end{array}$ & $\begin{array}{l}\text { Pacifie } \\
\text { (13) }\end{array}$ & $\begin{array}{l}\text { Earibbean } \\
\text { (14) }\end{array}$ \\
\hline Population (ln) & $\begin{array}{c}0.186^{* * *} \\
(0.054)\end{array}$ & $\begin{array}{c}0.126^{* *} \\
(0.057)\end{array}$ & $\begin{array}{l}0.090^{*} \\
(0.051)\end{array}$ & $\begin{array}{c}0.198^{* * *} \\
(0.054)\end{array}$ & $\begin{array}{c}0.167 * * * \\
(0.048)\end{array}$ & $\begin{array}{c}0.160^{* * *} \\
(0.050)\end{array}$ & $\begin{array}{l}0.061 * \\
(0.036)\end{array}$ & $\begin{array}{c}0.147 * * * \\
(0.056)\end{array}$ & $\begin{array}{c}0.154 * * * \\
(0.047)\end{array}$ & $\begin{array}{c}0.149 * * * \\
(0.052)\end{array}$ & $\begin{array}{c}0.157 * * * \\
(0.049)\end{array}$ & $\begin{array}{c}0.156^{* * *} \\
(0.052)\end{array}$ & $\begin{array}{c}0.149 * * * \\
(0.047)\end{array}$ & $\begin{array}{c}0.153^{* * *} \\
(0.048)\end{array}$ \\
\hline GDP per cap (ln) & $\begin{array}{c}0.207 * * \\
(0.094)\end{array}$ & $\begin{array}{c}0.468^{* * *} \\
(0.083)\end{array}$ & $\begin{array}{c}0.678^{* * *} \\
(0.087)\end{array}$ & $\begin{array}{c}0.370^{* * *} \\
(0.075)\end{array}$ & $\begin{array}{c}0.434 * * * \\
(0.075)\end{array}$ & $\begin{array}{c}0.459 * * * \\
(0.076)\end{array}$ & $\begin{array}{c}0.612 * * * \\
(0.045)\end{array}$ & $\begin{array}{c}0.407 * * * \\
(0.079)\end{array}$ & $\begin{array}{c}0.305^{* * * *} \\
(0.092)\end{array}$ & $\begin{array}{c}0.455^{* * *} \\
(0.075)\end{array}$ & $\begin{array}{c}0.459 * * * \\
(0.075)\end{array}$ & $\begin{array}{c}0.446 * * * \\
(0.077)\end{array}$ & $\begin{array}{c}0.454 * * * \\
(0.072)\end{array}$ & $\begin{array}{c}0.448^{* * *} \\
(0.073)\end{array}$ \\
\hline Countries & 129 & 141 & 133 & 154 & 126 & 135 & 135 & 109 & 134 & 149 & 145 & 148 & 154 & 151 \\
\hline Years (max) & 153 & 145 & 119 & 33 & 153 & 153 & 153 & 153 & 126 & 153 & 153 & 153 & 153 & 153 \\
\hline Observations & 4,695 & 4,058 & 4,279 & 4,340 & 8,045 & 7,116 & 7,916 & 6,892 & 6,241 & 8,422 & 8,322 & 8,454 & 8,753 & 8,616 \\
\hline R-squared & 0.0577 & 0.236 & 0.183 & 0.165 & 0.152 & 0.169 & 0.238 & 0.110 & 0.0771 & 0.153 & 0.161 & 0.154 & 0.154 & 0.153 \\
\hline
\end{tabular}

Notes: Outcome: institutionalization index (additive). Right-side variables lagged 20 years. Estimator: ordinary least squares, country clustered standard errors in brackets. $* * * ~ p<0.01$, ${ }^{* *} \mathrm{p}<0.05,{ }^{*} \mathrm{p}<0.10$ 


\section{Appendix D: Size and Diversity}

In the first part of the argument (Section I), we make the assumption that larger polities have a larger number of elites, each with their own support base. This presumes that size correlates with diversity. However, it is not a simple point, so we expatiate on the idea in this appendix and offer some corroborating evidence.

Let us imagine that a set of political communities are generated by drawing samples randomly from a population. Let us further stipulate that some of the samples are small and others are large, generating small and large communities. Within the large communities we would expect to find greater heterogeneity - e.g., more ethnicities, more languages, more religions, more ideologies, more economic sectors, and so forth - than in the smaller communities.

The distribution of features (cultural, economic, ideological et al.) will be similar across communities of various sizes. If one is sampling from a population randomly there is no reason to expect a larger sample to have a very different distribution than a smaller sample. Each group in the population will register roughly the same proportion in all samples, large or small. However, more rare events (judged by their frequency in the population) will be captured in a large sample than in a small sample. Thus, the range of variation will be greater for attributes with a continuous distribution, i.e., more "extreme" cases (measured as absolute numbers of cases) at each tail. And for attributes that may be understood as nominal categories (e.g., ethnic or linguistic groups) one is likely to have a larger set of categories represented in a large sample than in a small sample, e.g., a greater variety of ethnic or linguistic groups.

The point is bolstered when one considers the social and political viability of groups. Miniscule groups may not be large enough to sustain themselves demographically, and are likely to die out or diffuse over time. Miniscule groups are also at pains to influence political outcomes. Larger groups, by contrast, are likely to be more enduring and more viable - economically, politically, sociologically, and demographically. They can maintain organizations (e.g., clubs, fraternities, churches, trade associations, hobbyist groups, newspapers) and social practices (e.g., street festivals, holidays, protests, religious rituals). The larger the population pool, the more of these activities can be sustained. This reinforces our supposition that larger populations are able to create and sustain greater internal heterogeneity.

Large communities, by virtue of their size, may even encourage greater heterogeneity. In a community of millions, it is often hard to find one's place. This sort of community is necessarily diffuse, by virtue of being so encompassing. Gemeinschaft does not come naturally in a very large group. Consequently, individuals look for smaller units that form a tighter fit to their interests and values, and that provide a stronger sense of community. ${ }^{5} \mathrm{~A}$ case can be made that humans' ability to maintain meaningful relationships is limited by the size of our neocortex, and that core communities therefore have an optimal size measured in the hundreds rather than the thousands or millions (Dunbar 1992; Dunbar, Sosis 2017).

Although our discussion has focused on social groups the same relationship between scale and diversity should also exist among economic sectors. Kuznets (1963: 16) writes: "if we compared two nations,... one small and the other large, we would expect the range of economic activities to be wider in the latter than in the former." A larger society provides a larger base of workers, with a larger range of skills, a larger pool of capital to draw upon, and a larger group of consumers to sell products to. Together, this should encourage the development of a more

\footnotetext{
5 Typically, sub-groups within a larger population form among people who live in proximity to each other. However, distinctive social identities sometimes persist across vast territories, as is the case with diaspora communities. In the modern era, advanced communication and transportation networks facilitate non-proximal networks. In these respects, population - rather than territory - may be the relevant measure of size.
} 
diversified economy, which, in turn, should be related to a more diverse number of occupational groups, and perhaps even social groups.

With respect to empirical evidence, we mention, first, that a long tradition of sociological work examines the connection between community size and heterogeneity (Black 1974; Coser 1956: 144; Hwang, Murdock 1988; Milgram 1970; Sadalla 1978; Simmel 1950: 397; Wilson 1986; Wirth 1938).

Religion is a common focus of community studies. Ogburn, Duncan (1964: 142) report that the size of American cities is monotonically related to the number of religious denominations located in those cities. In 1936, small cities (pop: 25-50,000) housed an average of 24 denominations while big cities (pop: one million+) housed over one hundred.

Ideology is harder to define, but nonetheless essential to our topic. Levendusky and Pope (2010) exploit survey data from the Cooperative Congressional Survey Study (CCES) to estimate ideological diversity in states and congressional districts across the US. The latter is measured (a) as the variance of responses within a community (state or district) and (b) as the distance between the two primary groups within a community. With these measures, the authors conduct a multivariate regression analysis to explore various demographic features that might explain heterogeneity across US communities. Among a set of twelve predictors, only population (log) is found to be a significant predictor of both measures of heterogeneity, validating our claim that scale and diversity are strongly associated.

As a third measure, we turn to what is undoubtedly the most common empirical approach to heterogeneity, grounded in ethnic and/or linguistic identities. Sometimes, these concepts are distinguished; sometimes, they are considered together, with language being regarded a sign of ethnic identity. We use the composite term "ethnolinguistic" to encompass both elements.

In the following table we regress various measures of ethnic and/or linguistic diversity on population (log). Our benchmark model includes a single geographic covariate: latitude, measured as the distance of a country from the equator (log). This is widely regarded as a factor in economic and political development, and also shows a strong relationship with our measures of heterogeneity. In a second specification, we add a vector of region dummies. Both specifications are intended to be minimal, including only factors that are geographic and therefore strictly exogeneous. Since measures of ethnolinguistic identity are fairly stable over time, we focus our analyses on a single year -2000 .

The first set of regression tests focuses on a distributional measure of heterogeneity, the Herfindahl index of fractionalization, which measures the probability that two randomly chosen individuals from a population will be members of the same group. Measures of ethnic, linguistic, and ethnolinguistic fractionalization are drawn from work by Alesina, Devleeschauwer, Easterly, Kurlat, Wacziarg (2003) and Fearon (2003). It will be seen that there is scarcely any relationship between the size of countries and their heterogeneity by this measure, confirming our hunch that the distributional aspects of heterogeneity are unrelated to population size (see also Anckar 1999).

Next, we examine the absolute number of groups within each country, using data on linguistic groups compiled by Michalopoulos (2012) from the World Language Mapping System (2006). This is essential for our purposes as it counts all languages spoken by more than 1,000 inhabitants. Other sources, including Alesina et al. and Fearon, generally count only groups that are fairly large in proportion to the total population. This truncates the available data in an arbitrary - and for our purposes, biased - fashion, as it means that small groups are more likely to be counted in a small country (where they comprise a sizeable proportion of the total population) than in a large country (where their proportion is negligible). Indeed, the number of languages per country counted by Michalopoulos far outstrips the number of languages counted by other sources. 
To identify the relationship between heterogeneity and population we begin by replicating our previous specifications. Model 7 includes only latitude (log). Model 8 adds a vector of regional dummies, which we regard as our benchmark specification. These tests tests reveal a strong association between population and linguistic diversity.

\section{Table D1: Population Size and Diversity}

\begin{tabular}{|c|c|c|c|c|c|c|c|c|}
\hline \multirow{3}{*}{$\begin{array}{l}\text { Outcome } \\
\text { Source } \\
\text { Estimators }\end{array}$} & \multicolumn{6}{|c|}{ Distributional measures } & \multirow{2}{*}{\multicolumn{2}{|c|}{$\begin{array}{c}\text { Absolute measures } \\
\begin{array}{c}\text { Number of Groups } \\
\text { (log) }\end{array} \\
\text { (Michalopoulos) }\end{array}$}} \\
\hline & \multicolumn{2}{|c|}{$\begin{array}{l}\text { Ethnic Fract } \\
\text { (Alesina et al.) }\end{array}$} & \multicolumn{2}{|c|}{$\begin{array}{l}\text { Linguistic Fract } \\
\text { (Alesina et al.) }\end{array}$} & \multicolumn{2}{|c|}{$\begin{array}{c}\text { Ethnolinguistic Fract } \\
\text { (Fearon) }\end{array}$} & & \\
\hline & OLS & OLS & OLS & OLS & OLS & OLS & OLS & OLS \\
\hline Model & 1 & 2 & 3 & 4 & 5 & 6 & 7 & 8 \\
\hline Population (log) & $\begin{array}{l}0.018^{*} \\
(0.098)\end{array}$ & $\begin{array}{c}0.008 \\
(0.012)\end{array}$ & $\begin{array}{c}0.017 \\
(0.011)\end{array}$ & $\begin{array}{c}0.012 \\
(0.012)\end{array}$ & $\begin{array}{l}-0.006 \\
(0.012)\end{array}$ & $\begin{array}{l}0.020^{*} \\
(0.011)\end{array}$ & $\begin{array}{c}0.506^{* * *} \\
(0.062)\end{array}$ & $\begin{array}{c}0.562^{* * *} \\
(0.069)\end{array}$ \\
\hline $\begin{array}{l}\text { Latitude (log) } \\
\text { Region dummies }\end{array}$ & $\checkmark$ & $\begin{array}{l}\checkmark \\
\checkmark\end{array}$ & $\checkmark$ & $\begin{array}{l}\checkmark \\
\checkmark\end{array}$ & $\checkmark$ & $\begin{array}{l}\checkmark \\
\checkmark\end{array}$ & $\checkmark$ & $\begin{array}{l}\checkmark \\
\checkmark\end{array}$ \\
\hline Ccountries & 181 & 181 & 175 & 175 & 153 & 153 & 149 & 149 \\
\hline$R^{2}$ & 0.146 & 0.361 & 0.074 & 0.370 & 0.219 & 0.476 & 0.411 & 0.589 \\
\hline
\end{tabular}

Units of analysis: countries. Year: 2000 (approximate). Constant omitted. Estimators: OLS (ordinary least squares), 2SLS (two-stage least squares, using land area and agricultural suitability as instruments), robust standard errors. *** $\mathrm{p}<0.01, * * \mathrm{p}<0.05, * \mathrm{p}<0.10$ (two-tailed tests)

It is true that the foregoing analysis addresses social groups, not elites. The latter are harder to measure as one must define who qualifies as an "elite," a matter that is not self-evident. However, a reasonable proxy is the size of a country's legislature. Legislatures are intended to represent a country's entire population and can be enlarged (or reduced) in size to suit this purpose. A number of studies have shown a relationship between the size of a polity and the size of its legislature. Taagepera (1972) examines the size of lower chamber (or unicameral) national legislatures in 1965. Auriol and Gary-Bobo (2012) replicate this exercise with more recent data and also examine US state legislatures. Taagepera and Recchia (2002) examine the size of upper chambers. Stigler (1976) examines national legislatures for non-communist states and lower chamber state legislatures in the US. All of these studies uncover a log-log relationship, suggesting that the numbers of these elite actors increase in a monotonic (but sublinear) fashion with population. 


\section{Appendix E: Alternative measures of institutionalized leadership succession}

This appendix contains the results from tests using alternative measures of our dependent variable, as discussed in the paper. The results are reported in Table E1, and the five first columns (from the left) report versions of our main, additive index, but where we take out one of the indicators. The next two columns report results from regressions where the dependent variable is a first component from a PCA analysis run on the five indicators. The next two columns use a binary measure as a dependent variable, where high score is required on all five indicators for high score on the aggregated binary index (thus following a logical complementarities logic). The final two columns use a dependent variable that is a (factual) proxy of (the lack of) leadership institutionalization, measuring the length of tenure of the incumbent leader. Our main result on the positive relationship between population size and leadership institutionalization remains robust across these different measures. 
Table E1: Alternate Measures

\begin{tabular}{|c|c|c|c|c|c|c|c|c|c|c|c|}
\hline \multirow{3}{*}{$\begin{array}{l}\text { Institutionalization } \\
\text { Estimator }\end{array}$} & $\begin{array}{l}\text { Regular } \\
\text { departure }\end{array}$ & $\begin{array}{l}\text { Exec at } \\
\text { liberty }\end{array}$ & $\begin{array}{l}\text { itive, minu } \\
\text { Accession } \\
\text { regular }\end{array}$ & $\begin{array}{c}\text { No } \\
\text { nepotism }\end{array}$ & $\begin{array}{c}\text { Tenure } \\
\leq 10 \text { years }\end{array}$ & \multicolumn{2}{|c|}{ PCA } & \multicolumn{2}{|c|}{ Binary } & \multicolumn{2}{|c|}{ Tenure } \\
\hline & & & OLS & & & \multicolumn{2}{|c|}{ OLS } & \multicolumn{2}{|c|}{ Logit } & \multicolumn{2}{|c|}{ OLS } \\
\hline & (1) & (2) & (3) & (4) & (5) & (6) & (7) & (8) & (9) & (10) & (11) \\
\hline Population (ln) & $\begin{array}{c}0.117 * * * \\
(0.034)\end{array}$ & $\begin{array}{c}0.147^{* * *} \\
(0.038)\end{array}$ & $\begin{array}{c}0.130 * * * \\
(0.038)\end{array}$ & $\begin{array}{c}0.128^{* * *} \\
(0.042)\end{array}$ & $\begin{array}{c}0.130^{* * *} \\
(0.040)\end{array}$ & $\begin{array}{c}0.162^{* * *} \\
(0.047)\end{array}$ & $\begin{array}{c}0.146^{* * *} \\
(0.048)\end{array}$ & $\begin{array}{c}0.280^{* * *} \\
(0.091)\end{array}$ & $\begin{array}{c}0.197 * * * \\
(0.072)\end{array}$ & $\begin{array}{c}-0.710^{* *} \\
(0.321)\end{array}$ & $\begin{array}{c}-0.490 * * \\
(0.216)\end{array}$ \\
\hline GDP per cap (ln) & $\begin{array}{c}0.254^{* * *} \\
(0.069)\end{array}$ & $\begin{array}{c}0.303^{* * *} \\
(0.100)\end{array}$ & $\begin{array}{c}0.211^{* *} \\
(0.093)\end{array}$ & $\begin{array}{c}0.377^{* * *} \\
(0.093)\end{array}$ & $\begin{array}{c}0.320^{* * *} \\
(0.082)\end{array}$ & $\begin{array}{c}0.378^{* * *} \\
(0.107)\end{array}$ & $\begin{array}{c}0.484 * * * \\
(0.072)\end{array}$ & $\begin{array}{c}0.690^{* * *} \\
(0.251)\end{array}$ & $\begin{array}{c}0.829 * * * \\
(0.114)\end{array}$ & $\begin{array}{l}-1.031 \\
(1.040)\end{array}$ & $\begin{array}{c}-1.117 * * * \\
(0.298)\end{array}$ \\
\hline Urbanization & $\begin{array}{c}0.002 \\
(0.003)\end{array}$ & $\begin{array}{c}0.004 \\
(0.004)\end{array}$ & $\begin{array}{c}0.006 \\
(0.004)\end{array}$ & $\begin{array}{c}0.004 \\
(-0.004)\end{array}$ & $\begin{array}{c}0.004 \\
(0.003)\end{array}$ & $\begin{array}{c}0.005 \\
(0.004)\end{array}$ & & $\begin{array}{c}0.014 \\
(0.009)\end{array}$ & & $\begin{array}{l}-0.006 \\
(0.038)\end{array}$ & \\
\hline Years indep (ln) & $\begin{array}{c}-0.006 \\
(-0.026)\end{array}$ & $\begin{array}{l}-0.029 \\
(-0.031)\end{array}$ & $\begin{array}{c}-0.002 \\
(-0.032)\end{array}$ & $\begin{array}{l}-0.010 \\
(-0.037)\end{array}$ & $\begin{array}{c}-0.018 \\
(-0.032)\end{array}$ & $\begin{array}{l}-0.014 \\
(0.040)\end{array}$ & & $\begin{array}{l}-0.001 \\
(0.081)\end{array}$ & & $\begin{array}{l}-0.112 \\
(0.288)\end{array}$ & \\
\hline State history & $\begin{array}{c}-0.188 \\
(-0.223)\end{array}$ & $\begin{array}{c}-0.014 \\
(-0.273)\end{array}$ & $\begin{array}{c}-0.156 \\
(-0.289)\end{array}$ & $\begin{array}{c}-0.314 \\
(-0.301)\end{array}$ & $\begin{array}{c}-0.272 \\
(-0.314)\end{array}$ & $\begin{array}{l}-0.270 \\
(0.348)\end{array}$ & & $\begin{array}{c}0.134 \\
(0.733)\end{array}$ & & $\begin{array}{l}-1.223 \\
(1.792)\end{array}$ & \\
\hline Year dummies & $\checkmark$ & $\checkmark$ & $\checkmark$ & $\checkmark$ & $\checkmark$ & $\checkmark$ & & $\checkmark$ & & $\checkmark$ & \\
\hline Region dummies & $\checkmark$ & $\checkmark$ & $\checkmark$ & $\checkmark$ & $\checkmark$ & $\checkmark$ & & $\checkmark$ & & $\checkmark$ & \\
\hline Countries & 98 & 98 & 98 & 98 & 98 & 98 & 154 & 92 & 154 & 98 & 154 \\
\hline Years (max) & 136 & 136 & 136 & 136 & 136 & 136 & 153 & 134 & 153 & 136 & 153 \\
\hline Observations & 6,059 & 6,059 & 6,059 & 6,059 & 6,059 & 6,059 & 8,753 & 5,839 & 8,753 & 6,059 & 8,756 \\
\hline $\mathrm{R}^{2}$ (pseudo) & 0.319 & 0.348 & 0.304 & 0.346 & 0.333 & 0.351 & 0.156 & $(0.263)$ & $(0.106)$ & 0.178 & 0.0254 \\
\hline
\end{tabular}

Notes: Outcomes: various measures of institutionalization. Estimators: OLS (ordinary least squares), Logit (logistic regression). Country clustered standard errors in brackets. $* * * ~ p<0.01, * *$ $\mathrm{p}<0.05, * \mathrm{p}<0.10$ 


\section{Appendix References}

Alesina, Alberto, Arnaud Devleeschauwer, William Easterly, Sergio Kurlat, Romain Wacziarg. 2003. "Fractionalization." Journal of Economic Growth 8:2, 155-94.

Beck, Thorsten, George Clarke, Alberto Groff, Philip Keefer, Patrick Walsh. 2001. "New Tools and New Tests in Comparative Political Economy: The Database of Political Institutions." World Bank Economic Review 15:1 (September) 165-76.

Black, Gordon S. (1974). Conflict in the Community: A Theory of the Effects of Community Size. American Political Science Review, 68(3), 1245-61.

Bolt, Jutta, Jan Luiten van Zanden. 2014. "The Maddison Project: Collaborative Research on Historical National Accounts." The Economic History Review 67(3):627-651.

Brecke, Peter. 2013. "Violent Conflicts 1400 A.D. to the Present in Different Regions of the World.” Dataset.

Coppedge, Michael, John Gerring, Staffan I. Lindberg, Jan Teorell, David Altman, Michael Bernhard, M. Steven Fish, Adam Glynn, Allen Hicken, Carl Henrik Knutsen, Kelly McMann, Daniel Pemstein, Megan Reif, Svend-Erik Skaaning, Jeffrey Staton, Eitan Tzelgov, Yi-ting Wang, Brigitte Zimmerman. 2016. "Varieties of Democracy (V-Dem) Dataset. v.5." Varieties of Democracy (V-Dem) Project.

Coser, Lewis (1956). The Functions of Social Conflict. New York: The Free Press.

Dunbar, Robin I.M. \& Richard Sosis (2017). Optimising Human Community Sizes. Evolution and Human Behavior (forthcoming).

Dunbar, Robin I.M. (1992). Neocortex Size as a Constraint on Group Size in Primates. Journal of Human Evolution, 22(6), 469-93.

Elkins, Zachary, Tom Ginsburg, James Melton. 2009. The Endurance of National Constitutions. Cambridge: Cambridge University Press.

Fearon, James D. (2003). Ethnic and Cultural Diversity by Country. Journal of Economic Growth, 8(2), 195-222.

Gleditsch, Kristian S., Michael D. Ward. 1997. "Double Take: A Reexamination of Democracy and Autocracy in Modern Polities." Journal of Conflict Resolution 41:3 (June) 361-83.

Gleditsch, Nils Petter, Peter Wallensteen, Mikael Eriksson, Margareta Sollenberg, Håvard Strand. 2002. “Armed Conflict 1946-2001: A New Dataset.” Journal of Peace Research 39:5, 615-637.

Goemans, Hein E., Kristian Skrede Gleditsch, Giacomo Chiozza. 2016. “ARCHIGOS A Data Set on Leaders 1875-2015, Version 4.1.” (February 28). Downloaded (2016 07 16): http://privatewww.essex.ac.uk/ ksg/papers/Archigos-27-Feb-2016.pdf

Goldewijk, Kees Klein, A.H.W. Beusen, Peter Janssen. 2010. "Long term dynamic modeling of global population and built-up area in a spatially explicit way, HYDE 3 .1." The Holocene 20:4, 565573.

Haber, Stephen, Victor Menaldo. 2011. "Do Natural Resources Fuel Authoritarianism? A Reappraisal of the Resource Curse." American Political Science Review 105:1, 1-26. 
Henisz, Witold J. 2002. “The Institutional Environment for Infrastructure Investment." Industrial and Corporate Change 11:2, 355-89.

Hwang, Sean-Shong \& Steve H. Murdock (1988). Residential Segregation and Ethnic Identification among Hispanics in Texas. Urban Affairs Quarterly, 23(3), 329-45.

Kuznets, Simon (1963). Economic growth of small nations. In E.A.G. Robinson eds., Economic Consequences of the Size of Nations. London: Macmillan, pp. 14-34.

Levendusky, Matthew S. \& Jeremy C. Pope (2010). Measuring Aggregate-Level Ideological Heterogeneity. Legislative Studies Quarterly, 35(2), 259-82.

Marshall, Monty, Ted Gurr, Keith Jaggers. 2014. Polity IV project: Dataset users' manual. http://www.systemicpeace.org/inscr/p4manualv2013.pdf

Michalopoulos, Stelios (2012). The Origins of Ethnolinguistic Diversity. American Economic Review, 102(4), 1508-39.

Milgram, Stanley (1970). The Experience of Living in Cities. Science, 167(3924), 1461- 68.

Ogburn, William F. \& Otis Dudley Duncan (1964). City Size as a Sociological Variable. In Ernest W. Burgess and Donald J. Bogue eds., Contributions to Urban Sociology. Chicago: University of Chicago Press, pp. 129-147.

Putterman, Louis, David N. Weil. 2010. "Post-1500 Population Flows and the Long-Run Determinants of Economic Growth and Inequality." Quarterly Journal of Economics 125:4, 1627-82.

Sadalla, Edward K. (1978). Population Size, Structural Differentiation, and Human Behavior. Environment and Behavior, 10(2), 271-91.

Sarkees, Meredith Reid, Frank Wayman. Resort to War: 1816-2007. Washington D.C.: CQ Press. Simmel, Georg (1950). The Sociology of Georg Simmel. New York: The Free Press.

Wilson, Thomas C. (1986). Community Population Size and Social Heterogeneity: An Empirical Test. American Journal of Sociology, 91(5), 1154-69.

Wirth, Louis (1938). Urbanism as a Way of Life. American Journal of Sociology, 44(1), 1-24. 